\title{
Yeast telomeres exert a position effect on recombination between internal tracts of yeast telomeric DNA
}

\author{
Jeffrey B. Stavenhagen ${ }^{1,2}$ and Virginia A. Zakian \\ Princeton University, Department of Molecular Biology, Princeton, N ew Jersey 08544-1014 USA; ${ }^{1}$ Biology Department, \\ University of Dayton, Dayton, Ohio 45469-2320 USA.
}

\begin{abstract}
In Saccharomyces cerevisiae, proximity to a telomere affects both transcription and replication of adjacent DNA. In this study, we show that telomeres also impose a position effect on mitotic recombination. The rate of recombination between directly repeated tracts of telomeric $C_{1-3} A / T G_{1-3}$ DNA was reduced severely by proximity to a telomere. In contrast, recombination of two control substrates was not affected by telomere proximity. Thus, unlike position effects on transcription or replication, inhibition of recombination was sequence specific. Moreover, the repression of recombination was not under the same control as transcriptional repression (telomere position effect; TPE), as mutations in genes essential for TPE did not alleviate telomeric repression of recombination. The reduction in recombination between $C_{1-3} A / T G_{1-3}$ tracts near the telomere was caused by an absence of Rad52p-dependent events as well as a reduction in Radlp-dependent events. The sequence-specific repression of recombination near the telomere was eliminated in cells that overexpressed the telomere-binding protein Raplp, a condition that also increased recombination between $C_{1-3} A / T G_{1-3}$ tracts at intemal positions on the chromosome. We propose that the specific inhibition between $\mathrm{C}_{1-3} \mathrm{~A} / \mathrm{TG}_{1-3}$ tracts near the telomere occurs through the action of a telomere-specific end-binding protein that binds to the single-strand $\mathrm{TG}_{1-3}$ tail generated during the processing of recombination intermediates. The recombination inhibitor protein may also block recombination between endogenous telomeres.
\end{abstract}

[Key Words: Telomeres; recombination; yeast; position effect; tel omere replication]

Received A pril 29, 1998; revised version accepted August 3, 1998.

In most organisms, telomeres consist of simple repetitive DN A. For example, each end of each Saccharomyces chromosome bears $\sim 300$ bp of $C_{1-3} A / T G_{1-3} D N A$. Telomeres are required for the stable maintenance and segregation of yeast chromosomes (Sandell and Zakian 1993). In most organisms, including yeast, telomeric DN A is replicated by telomerase, a telomere-specific reverse transcri ptase (for review, see Grei der 1995). Tel omerase extends the G-strand of telomeric DNA using its RNA component as a template. Telomerase-independent pathways for telomere replication al so exist. In yeasts (Lundblad and Blackburn 1993; M cEachern and Blackburn 1995; Lendvay et al. 1996) and human cells in culture (Murnane et al. 1994; de Lange 1995; Rogan et al . 1995), tel omere-tel omere recombination can maintain telomeric DNA in the absence of telomerase. In some insects, recombination is probably the sole pathway for maintenance of telomeric DNA (Biessmann et al. 1996; Lopez et al. 1996).

\footnotetext{
1Present address: Biology Department, University of Dayton, Dayton, Ohio 45469-2320 USA.

${ }^{2}$ Corresponding author.

E-MAIL stavenha@neelix.udayton.edu; FAX (937) 229-2021.
}

The subtelomeric regions of chromosomes from many organisms, including yeast, consist of a variable array of middle repetitive DN A with the variability caused, at least in part, by homologous recombination among the repeats (Brown et al. 1990; Louis et al. 1994). In yeast, the number and identity of these middle repetitive el ements vary, both from strain to strain and from chromosome to chromosome. In addition, in yeast, thereare often interstitial tracts of telomeric DN A interspersed among the middle repetitive elements (Walmsley et al. 1984; Louis et al. 1994). Interstitial tracts of telomeric sequence exist in many other organisms, including mammals (M eyne et al. 1990; Cheung et al. 1994). In mammals, these tracts are not limited to subtelomeric regions of chromosomes and are believed to act as recombination hot spots (Park et al. 1992; Ashley and Ward 1993; A shley 1994; Henderson 1995). In both yeast and mammals, short stretches of the telomerelike sequence poly(GT) increase recombination rates (Stringer 1985; Treco and Arnheim 1986; White et al. 1991). The preference for GT-rich DNA displayed in vitro by at least some strand transfer proteins may contribute to the elevated recombination rates of telomeric and telomere-like DNAs (Tracey et al. 1996, 1997). 
In meiosis, telomeres themselves affect recombination. For example, molecular and cytological studies show reduced meiotic crossing-over in telomeric regions of grasshopper chromosomes (Miklos and Nankivell 1976). Most relevant for our studies, double-strand breaks, which initiate most meiotic recombination events, are absent in the terminal $\sim 25 \mathrm{~kb}$ of yeast chromosomes (Klein et al. 1996). In contrast, cytological and genetic evidence suggests that meiotic recombination occurs at elevated rates near some human telomeres (Ashley 1994; Kipling et al. 1996).

In mitotic cells, yeast telomeres affect the replication and transcription of nearby DNA. Proximity to a yeast telomere el iminates (Reynolds et al. 1989; Dubey et al. 1991; Zhu et al. 1992) or delays (Ferguson and Fangman 1992; Wellinger et al. 1993) activation of replication origins. Transcription of genes near tel omeres is repressed in yeast (Gottschling et al. 1990) and other organisms (Levis et al. 1985; Nimmo et al. 1994; Horn and Cross 1995; Rudenko et al. 1995), a phenomenon called telomere position effect (TPE). In S. cerevisiae, transcriptional repression is not limited to telomeres, as interstitial tracts of $\mathrm{C}_{1-3} \mathrm{~A}_{\mathrm{T}} \mathrm{TG}_{1-3}$ DNA integrated onto the chromosome also repress transcription, even on circular chromosomes (Stavenhagen and Zakian 1994).

The tel omeric $\mathrm{C}_{1-3} \mathrm{~A} / \mathrm{TG}_{1-3}$ repeats are organized into a non-nucleosomal protein-DNA structure, called the telosome (Wright et al. 1992). The major protein in the yeast telosome is the essential (Shore and Nasmyth 1987) duplex DN A-binding protein Rap1, present in 1020 molecules per telomere (Conrad et al. 1990; Klein et al. 1992; Wright et al. 1992; Gilson et al. 1993; Wright and Zakian 1995). RAP1 is important for TPE and telomere length control (see Kyrion et al. 1992, 1993; Marcand et al. 1997).

Raplp mediates its effects on tel omeres at least in part through its interactions with other proteins. The carboxyl terminus of Raplp interacts with Sir3p, Sir4p, Rif1p, and Rif2p (Hardy et al. 1992; Moretti et al. 1994; Wotton and Shore 1997). Sir2p interacts with Sir4p and Sir3p (Moazed et al. 1997) and hence indirectly with Rap1p. Sir2p, Sir3p, Sir4p, Rif1p, and Rif2p are telosomal proteins in vivo as is, Cdc13p (Bourns et al. 1998), a protein that binds single-strand $\mathrm{TG}_{1-3}$ DNA in vitro (Lin and Zakian 1996; N ugent et al. 1996). Sir2p, Sir3p, and Sir4p are essential for TPE (A paricio et al. 1991) as well as for silencing at internal tracts of telomeric DNA (Stavenhagen and Zakian 1994) whereas Rif1p and Rif2p function cooperatively to limit telomere length (Wotton and Shore 1997). The phenotypes of cells limited for the essential Cdc13p suggest that it regulates access of both telomerase (N ugent et al. 1996) and nucl eases (Garvik et al. 1995) to telomeric DNA. In wild-type cells, Raplp and the three Sir proteins are concentrated in foci near the nuclear peri phery that correspond to clusters of telomeres (Gotta et al. 1996, 1997; Palladino et al. 1993).

This paper presents a study of recombination between telomeric sequences at both subtelomeric loci and internal chromosomal sites. We found that recombination between $\mathrm{C}_{1-3} \mathrm{~A} / \mathrm{TG}_{1-3}$ tracts was decreased dramatically near the telomere, whereas recombination between two control sequences was not affected by tel omere proximity. The reduction in recombination between $\mathrm{C}_{1-3} \mathrm{~A}$ / $\mathrm{TG}_{1-3}$ tracts was caused in large part by the el imination of RAD52-dependent events although RAD1-dependent events were also reduced. Thus, yeast tel omeres exert a position effect on recombination between $\mathrm{C}_{1-3} \mathrm{~A}_{/} \mathrm{TG}_{1-3}$ sequences. Because this position effect did not require genes essential for TPE, telomere position effects on re combination were caused by a different mechanism than TPE.

\section{Results}

Direct-repeat recombination assay

Because of a long-term interest in the recombination behavior of telomeric DN A (Pluta and Zakian 1989; Wang and Zakian 1990), we devised a system to study recombination between two internal tracts of tel omeric $\mathrm{C}_{1-3} \mathrm{~A}$ / $T_{G_{1-3}}$ DNA as a function of the position of the tracts along the chromosome. In each experiment, both the rate of recombination and the structure of the recombination products were determined. As recombination was measured in haploid cells, the effects of different mutations on the recombination behavior of the tracts could be determined.

Three different classes of recombination substrates were constructed. Each of the three had two identical 300-bp tracts separated by a 4.6-kb segment of DNA that contained the URA3 gene (Fig. 1A). The three re combination substrates differed only in the identity of the sequence that comprised the $\sim 300 \mathrm{bp}$ tracts. The three substrates contained $\sim 300 \pm 25$ bp of either $\mathrm{C}_{1-3} \mathrm{~A}$ / $\mathrm{TG}_{1-3}$ DNA (Saccharomyces telomeric DNA), $\mathrm{C}_{4} \mathrm{~A}_{2} /$ $\mathrm{T}_{2} \mathrm{G}_{4}$ DNA (Tetrahymena tel omeric DNA), or a unique sequence (a fragment from the Salmonella tetracyclineresistance gene). The base composition of the unique sequence tract was identical to that of $\mathrm{C}_{4} \mathrm{~A}_{2} / \mathrm{G}_{4} \mathrm{~T}_{2} \mathrm{DNA}$ and similar to that of $\mathrm{C}_{1-3} \mathrm{~A} / \mathrm{TG}_{1-3}$. In contrast to the unique sequence tract, the $\mathrm{C}_{4} \mathrm{~A}_{2} / \mathrm{T}_{2} \mathrm{G}_{4}$ and $\mathrm{C}_{1-3} \mathrm{~A} / \mathrm{TG}_{1-3}$ tracts had two features in common: Both are internally repetitive and both are substrates for $\mathrm{C}_{1-3} \mathrm{~A} / \mathrm{TG}_{1-3}$ addition in yeast in vivo (Dani and Zakian 1983; Szostak 1983). Although theinternally repetitive $C_{4} A_{2} / T_{2} G_{4}$ and $\mathrm{C}_{1-3} \mathrm{~A} / \mathrm{TG}_{1-3}$ tracts can both align in multiple registers, $\mathrm{C}_{1-3} \mathrm{~A} / \mathrm{TG}_{1-3} \mathrm{DNA}$, an imperfect repeat, can al so align with mismatches between base pairs. Therefore $\mathrm{C}_{1-3} \mathrm{~A}$ / $\mathrm{TG}_{1-3}$ direct repeats can undergo both homologous and homeologous recombination. In addition, $\mathrm{C}_{1-3} \mathrm{~A}_{\mathrm{T}} \mathrm{TG}_{1-3}$ DNA is the only one of the three substrates that is expected to be bound by theyeast tel omere-binding protein Raplp in vivo (Berman et al. 1986; Conrad et al. 1990; Klein et al. 1992).

Each recombination substrate was integrated at five different chromosomal loci in a haploid strain: These sites were $\sim 4$ and $17 \mathrm{~kb}$ from the right telomere of chromosome $V$ and $\sim 5,20$, and $200 \mathrm{~kb}$ from the left telomere of chromosome VII. In each case, LYS2 was placed distal to the recombination substrates (Fig. 1). Recombi- 
A

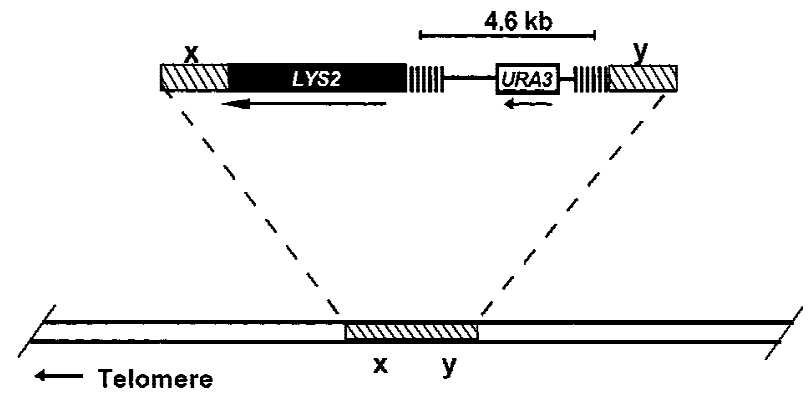

B

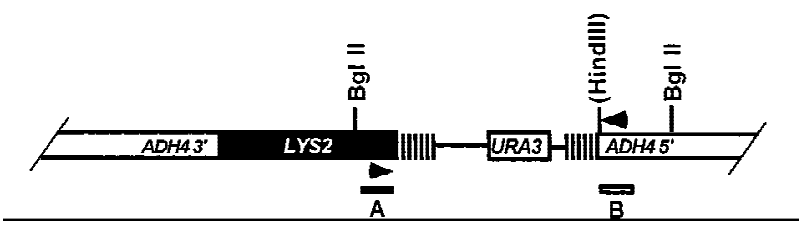

Figure 1. Structures of recombination substrates. General structure of recombination substrates. The identity of $x$ and $y$ vary depending on the site of integration for each particular construct. (A) U sing the homology provided by $x$ and $y$, integrative transformation was used to target plasmids to a specific site on chromosome V-R or chromosome VII-L in the orientation shown. The parallel vertical lines represent $\mathrm{a} \sim 300 \mathrm{bp}$ tract of either $C_{1-3} A / T G_{1-3}, C_{4} A_{2} / T_{2} G_{4}$, or unique sequence $D N A$. For the $\mathrm{C}_{1-3} \mathrm{~A} / \mathrm{TG}_{1-3}$ and $\mathrm{C}_{4} \mathrm{~A}_{2} / \mathrm{T}_{2} \mathrm{G}_{4}$ tracts, the $\mathrm{G}$-rich strand runs $5^{\prime} \rightarrow 3^{\prime}$ towards the telomere, in the same orientation as the endogenous telomere. The two copies of the tract are separated by $4.6 \mathrm{~kb}$ that contains the URA 3 gene and sequences derived from the vector YIp5. U pon integration, LYS2 is al ways distal to the direct repeats. The arrows bel ow the line indicate the direction of transcription of URA3 and LYS2. The diagram is not drawn to scale. (B) Genomic structure expected after recombination for substrates integrated $\sim 20 \mathrm{~kb}$ from the end of chromosome VII-L. Only the tel omere proximal regions of the chromosome are depicted. Symbols used are the same as above. The Hindlll site is present only in the control substrates. Arrowheads indicate positions of the PCR primers. The positions of the probes used in the Southern analysis are represented as bars (labeled A, LYS2, and B, ADH4) under the diagram of the chromosome.

nation rates were measured both in wild-type cells and in cells containing null mutations in genes that affect either TPE or recombination.

Recombination events were selected on plates containing 5-fluoro-orotic acid (FOA), which selects for cells lacking Ura3p (Boeke et al. 1987), and lacking lysine, which, by selecting for expression of LYS2, reduces transcriptional repression on U RA3. In the system used here, a U ra ${ }^{-}$Lys $^{+}$cell can be generated by intrachromosomal recombination, interchromosomal recombination, or sister chromatid exchange. For the $\mathrm{C}_{1-3} \mathrm{~A} / \mathrm{TG}_{1-3}$ substrates, interchromosomal recombination can occur between one of the internal $C_{1-3} A / T G_{1-3}$ tracts on the marked chromosome and the telomere of another chromosome. This event transfers LYS2 to a different chro- mosome. Although they proceed by different mechanisms, intrachromosomal recombination and sisterchromati d exchange are expected to generate products of identical structure in which the recombinant chromosome has a single copy of the original tract at an internal site. Because these two classes of events, intrachromosomal recombination and unequal sister chromatid exchange, could not be distinguished from each other in our study, these two classes of events will be referred to collectively as excision events.

In the system used in this study, two events other than recombination can yield an $\mathrm{FOA}^{\mathrm{R}}$ cell, transcriptional silencing of URA 3 and point mutations in URA3. To ensure that the reported rates were based solely on FOA ${ }^{R}$ cells that arose from recombination, the absence of the U RA 3 gene was establi shed by conventional Southern or PCR analysis on a subset of the recovered FOA ${ }^{R}$ cells in all genetic backgrounds examined (see below). In each experiment, FOA $^{\mathrm{R}}$ Lys $^{+}$events that were caused by transcriptional silencing or mutation of URA3 were subtracted before determining recombination rates.

Tel omeres specifically repress recombination between tracts of $\mathrm{C}_{1-3} \mathrm{~A}$ DNA

Recombination between either the $C_{4} A_{2} / T_{2} G_{4}$ or the unique sequence tracts, hereafter called the control substrates, occurred at similar rates at all five chromosomal loci (Fig. 2A,B). However, recombination between $\mathrm{C}_{1-3} \mathrm{~A} / \mathrm{TG}_{1-3}$ tracts was affected strongly by chromosomal position. Although recombination between $\mathrm{C}_{1-3} \mathrm{~A} / \mathrm{TG}_{1-3}$ tracts was lower than that of both controls at all five sites, by far the most dramatic difference among the three substrates was their recombination rates near the tel omere. Recombination between $\mathrm{C}_{1-3} \mathrm{~A}$ / $\mathrm{TG}_{1-3}$ tracts near the telomere occurred at rates 64- to 155-fold lower than the controls at the same site.

For example, on chromosome V-R (Fig. 2A), at both 4 and $17 \mathrm{~kb}$ from the telomere, recombination of the $\mathrm{C}_{4} \mathrm{~A}_{2} / \mathrm{T}_{2} \mathrm{G}_{4}$ and unique sequence tracts occurred at very similar rates, ranging from $2.8 \times 10^{-5}$ to $3.0 \times 10^{-5}$ events/cell division. At $17 \mathrm{~kb}$ from the tel omere, recombination between the $\mathrm{C}_{1-3} \mathrm{~A} / \mathrm{TG}_{1-3}$ tracts occurred at a rate 11 times lower than that seen for the two control substrates at the same locus. However, at $4 \mathrm{~kb}$ from the chromosome $\mathrm{V}$-R telomere, recombination between the $\mathrm{C}_{1-3} \mathrm{~A} / \mathrm{TG}_{1-3}$ tracts was even lower, occurring at a rate 100 or 155 times lower than for the two control substrates. These differences in rates were caused by a 13fold reduction in the rate of recombination between the $\mathrm{C}_{1-3} \mathrm{~A} / \mathrm{TG}_{1-3}$ tracts near the tel omere, rather than to an increase in recombination rates of the control sequences near the telomere (Fig. 2A).

A similar pattern was seen on chromosome VII-L. The rate of recombination between the $\mathrm{C}_{1-3} \mathrm{~A} / \mathrm{T} \mathrm{G}_{1-3}$ tracts was slightly lower, two- to eightfold, than the control substrates at both 20 and $200 \mathrm{~kb}$ from the telomere. However, recombination between the $C_{1-3} A / T G_{1-3}$ tracts $5 \mathrm{~kb}$ from the tel omere occurred at a rate 64 or 89 times lower than the two control substrates at the same 
Telomeres affect recombination in yeast

A

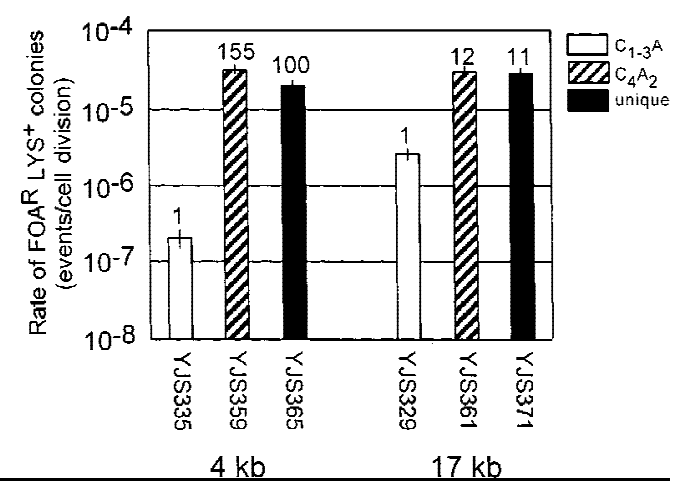

B

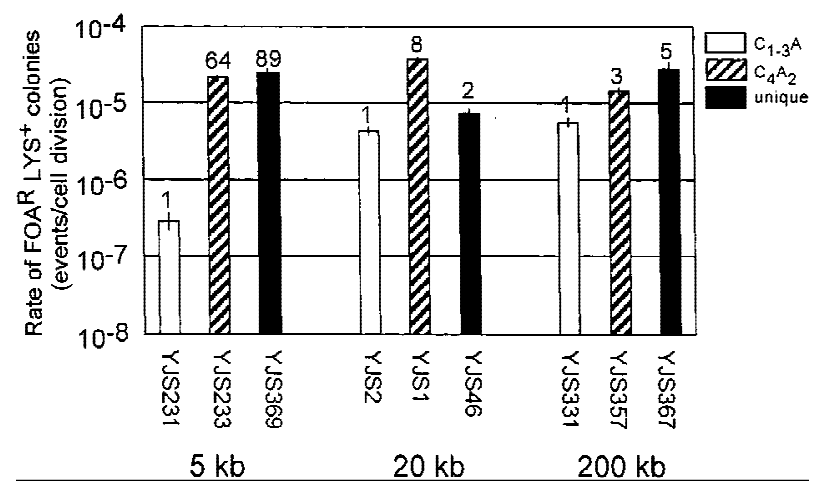

Figure 2. Rates of recombination in a wild-type strain. (A) Rates of recombination between direct repeats at different distances from the telomere on chromosome V-R. Strain names and the distance of the repeats relative to the telomere are indicated bel ow the bars on the $x$-axis. The $y$-axis indicates the recombination rates. The white columns are data for the $\mathrm{C}_{1-3} \mathrm{~A} / \mathrm{TG}_{1-3}$ substrates, the columns with diagonal lines are for $\mathrm{C}_{4} \mathrm{~A}_{2} / \mathrm{G}_{4} \mathrm{~T}_{2}$ substrates and the black columns are for the unique sequence substrate. The tops of the columns are the average median recombination rate from a minimum of four assays. The numbers above the columns represent the fold difference in recombination rate relative to the $\mathrm{C}_{1-3} \mathrm{~A}_{/} \mathrm{TG}_{1-3}$ direct-repeat strain at the same location. The error bars show standard deviations (Lea and Coulson 1949). The rates for $\mathrm{C}_{1-3} \mathrm{~A} / \mathrm{TG}_{1-3}$ directrepeat events are $2.0 \times 10^{-7}( \pm 0.6)$ events/cell division and $2.6 \times 10^{-6}( \pm 0.6)$ events/cell division for 4 and $17 \mathrm{~kb}$ from the telomere, respectively. (B) Rates of recombination between direct repeats at different distances from the telomere on chromosome VII-L. Interpretation of the graph is the same as in A. The rates for $\mathrm{C}_{1-3} \mathrm{~A} / \mathrm{TG}_{1-3}$ direct repeat events are $2.9 \times 10^{-7}$ $( \pm 0.8)$ events/cell division, $4.4 \times 10^{-6}( \pm 0.7)$ events/cell division and $5.6 \times 10^{-6}( \pm 0.9)$ events/cell division for 5 and $20 \mathrm{~kb}$ and 200 $\mathrm{kb}$ from the telomere, respectively.

Iocus (Fig. 2B). Recombination between the $\mathrm{C}_{1-3} \mathrm{~A} /$ $\mathrm{TG}_{1-3}$ tracts was $\sim 15$ - to 19-fold lower near the telomere than it was at the two internal sites on chromosome VII-L (Fig. 2B).

These data indicate that recombination between $\mathrm{C}_{1-3} \mathrm{~A} / \mathrm{TG}_{1-3}$ tracts was reduced by proximity to the telomere. Thus, the telomere imposed a position effect on recombination of $\mathrm{C}_{1-3} \mathrm{~A} / \mathrm{TG}_{1-3} \mathrm{DNA}$.

\section{Structure of the chromosomes after recombination}

For each strain and each recombination substrate, the resultant structure of chromosome V-R or chromosome VII-L was determined in at least 20 independent FOA ${ }^{\mathrm{R}}$ Lys $^{+}$ colonies using Southern hybridization or PCR analysis (Table 1, e.g., seeFig. 5, bel ow). This anal ysis demonstrated that $\mathrm{FOA}^{\mathrm{R}}$ colonies were generated by recombination, not transcriptional silencing nor mutation of URA3.

Recombination between direct repeats is expected to leave one copy of the repeat tract at an internal site on the chromosome bearing LYS2. Southern analysis was done by probing restriction-enzyme-digested-genomic DNA, BgllI-HindlII for the control strains and Bglll for the $\mathrm{C}_{1-3} \mathrm{~A} / \mathrm{TG}_{1-3}$ strains, with DNA fragments derived from the $5^{\prime}$-end of the LYS2 gene (Fig. 1B; probe A) and the $3^{\prime}$-end of the ADH4 gene (Fig. 1B; probe B). Events that occurred by either intrachromosomal recombination or sister chromatid exchange produced a fragment that hybridized to both probe A and B (Fig. 5C,D, below). Colony PCR was done using oligonucleotides complementary to region $A$ and region $B$ (see Fig. 1B; $M$ aterials and $M$ ethods).

The size of the remaining tract is presented for each of the three recombination substrates at each of the three loci on chromosome VII-L (T able 1). Recombination be tween two unique sequence tracts is expected to leave a tract identical in size to the 280-bp starting tract. This result was seen for 28 of 28 colonies examined. As expected, recombination between either $\mathrm{C}_{1-3} \mathrm{~A} / \mathrm{TG}_{1-3}$ or $\mathrm{C}_{4} \mathrm{~A}_{2} / \mathrm{T}_{2} \mathrm{G}_{4}$ tracts resulted in chromosomes with re maining tracts of variable size in different recombination events (Table 1 ). The fact that tracts of variable length were recovered demonstrated that, as expected, both the $\mathrm{C}_{1-3} \mathrm{~A} / \mathrm{T} \mathrm{G}_{1-3}$ and $\mathrm{C}_{4} \mathrm{~A}_{2} / \mathrm{T}_{2} \mathrm{G}_{4}$ tracts were able to al ign in multiple registers prior to compl etion of recombination. By this same criterion, proximity to the telomere affected the frequency but not the al ignment of the $\mathrm{C}_{1-3} \mathrm{~A}$ / $\mathrm{TG}_{1-3}$ tracts.

The structure of LYS2 in the recombination products also provides information on the mechanism of recombination. Because interchromosomal recombination transfers LYS2 to a different chromosome, recombinants produced by this path will have restriction fragments of novel sizes and will not yield a PCR product with the primers used. No interchromosomal recombination events were detected in the $\sim 150$ recombination products examined (Table 1), except in experiments in which Raplp was overexpressed (see below, Fig. 5). These data suggest that for the three substrates in each chromosomal location and in a vari ety of genetic backgrounds, most recombination events occurred by either intrachromosomal recombination or sister chromatid exchange.

Tel omeric repression of recombination between $\mathrm{C}_{1-3} \mathrm{~A} / \mathrm{TG}_{1-3}$ tracts is not alleviated by mutations in genes required for TPE

Mutations in SIR2, SIR3, or SIR4, eliminate position effects on transcription at the silent mating type loci (Rine 
Table 1. Summary of the products of chromosome VII-L excision events

\begin{tabular}{|c|c|c|c|c|c|c|c|}
\hline \multirow[b]{2}{*}{ Strain } & \multirow[b]{2}{*}{ Sequence } & \multirow{2}{*}{$\begin{array}{c}\text { Distance } \\
\text { from } \\
\text { telomere (kb) }\end{array}$} & \multirow{2}{*}{$\begin{array}{c}\text { No. of } \\
\text { samples }\end{array}$} & \multicolumn{4}{|c|}{ Tract length (bp) } \\
\hline & & & & $100-200$ & $200-300$ & $300-400$ & $400-500$ \\
\hline YJS231 & $C_{1-3} A$ & 5 & 20 & $10 \%$ & $45 \%$ & $40 \%$ & $5 \%$ \\
\hline YJS2 & $\mathrm{C}_{1-3} \mathrm{~A}$ & 20 & 16 & $6 \%$ & $69 \%$ & $25 \%$ & 0 \\
\hline YJS331 & $\mathrm{C}_{1-3} \mathrm{~A}$ & 200 & 5 & 0 & $60 \%$ & $40 \%$ & 0 \\
\hline YJS233 & $\mathrm{C}_{4} \mathrm{~A}_{2}$ & 5 & 10 & $40 \%$ & $10 \%$ & $40 \%$ & $10 \%$ \\
\hline YJS1 & $\mathrm{C}_{4} \mathrm{~A}_{2}$ & 20 & 19 & 0 & $47 \%$ & $53 \%$ & 0 \\
\hline YJS357 & $\mathrm{C}_{4} \mathrm{~A}_{2}$ & 200 & 10 & $30 \%$ & 0 & $30 \%$ & $40 \%$ \\
\hline YJS369 & Unique & 5 & 10 & 0 & $100 \%$ & 0 & 0 \\
\hline YJS46 & Unique & 20 & 10 & 0 & $100 \%$ & 0 & 0 \\
\hline YJS367 & Unique & 200 & 8 & 0 & $100 \%$ & 0 & 0 \\
\hline
\end{tabular}

Data are displayed as the percentage of excision events that resulted in tract lengths of the designated size. The approximate length was determined by either genomic Southern analysis for strains YJS2, YJS233, YJS1, YJS357, YJS46 or colony PCR for strains YJS231, YJS2, YJS357, YJS369, YJS367 (M aterials and M ethods).

and Herskowitz 1987), the telomere (Aparicio et al. 1991), and internal tracts of $\mathrm{C}_{1-3} \mathrm{~A} / \mathrm{TG}_{1-3}$ DN A (Stavenhagen and Zakian 1994). Intrachromosomal recombination at the rDNA locus is increased 19-fold in a sir2s strain (Gottlieb and Esposito 1989). To determine if the $\mathrm{SI} R$ genes are required for the repression of recombination between $\mathrm{C}_{1-3} \mathrm{~A} / \mathrm{TG}_{1-3}$ tracts near the telomere, the rate of recombination in strains containing null mutations in each of the three SIR genes was determined (Fig. 3). If the SIR genes were required for repression of recombination, then recombination between $C_{1-3} A / T G_{1-3}$ tracts should occur at an elevated rate in sir $\Delta$ strains compared to wild-type cells.

Contrary to this expectation, recombination between $\mathrm{C}_{1-3} \mathrm{~A} / \mathrm{TG}_{1-3}$ tracts near the tel omere was even lower in

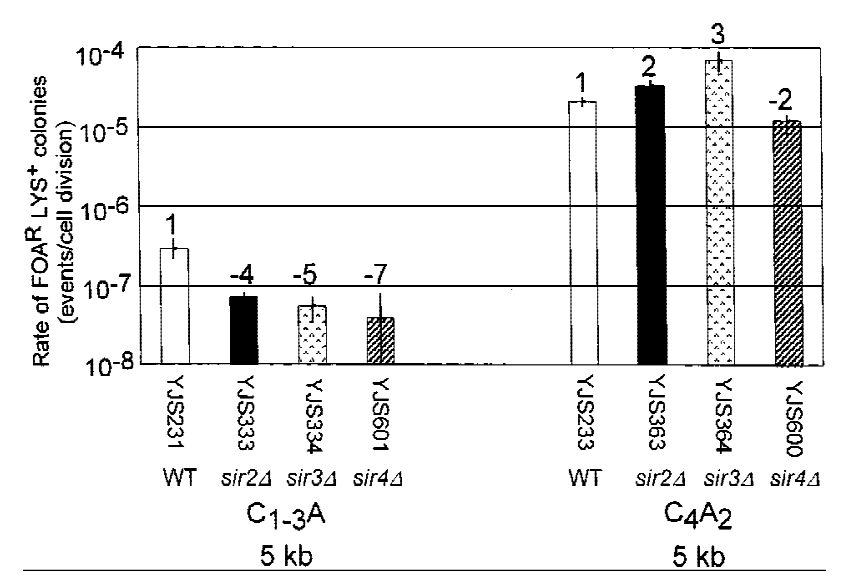

Figure 3. Rates of recombination in strains that lack transcriptional repression at telomeres. Rates were determined for recombination between $\mathrm{C}_{1-3} \mathrm{~A} / \mathrm{TG}_{1-3}$ (left) or $\mathrm{C}_{4} \mathrm{~A}_{2} / \mathrm{T}_{2} \mathrm{G}_{4}$ (right) tracts $5 \mathrm{~kb}$ from the chromosome VII-L telomere in wild-type, $\operatorname{sir} 2 \Delta$, sir $3 \Delta$, and sir $4 \Delta$ strains. Interpretation of the graph is the same as in Fig. 2A except that the average median recombination rate is based on a minimum of two assays. The numbers above the columns represent the fold difference in recombination rate for the same substrate relative to the wild-type strain at the same location. the three sir $\Delta$ strains than in wild-type cells (four- to sevenfold reduction, depending on strain; Fig. 3A). Recombination between $\mathrm{C}_{4} \mathrm{~A}_{2} / \mathrm{T}_{2} \mathrm{G}_{4}$ tracts was affected modestly in sir $\Delta$ strains (two- or threefold increase or twofold reduction depending on $\operatorname{sir} \Delta$ strain.) As a result, the differences in recombination rates near the tel omere were exacerbated in $\operatorname{sir} \Delta$ strains (225- to 965-fold lower recombination rates for $\mathrm{C}_{1-3} \mathrm{~A} / \mathrm{TG}_{1-3}$ tracts vs. $\mathrm{C}_{4} \mathrm{~A}_{2}$ / $\mathrm{T}_{2} \mathrm{G}_{4}$ tracts). Elimination of Sir proteins al so had modest inhibitory effects on $\mathrm{C}_{1-3} \mathrm{~A} / \mathrm{TG}_{1-3}$ tracts at $20 \mathrm{~kb}$ $\left[2.6 \times 10^{-6}( \pm 0.6)\right.$ events/cell division]. Similar recombination rates were found when sir $\Delta$ strains were grown in the presence of Iysine, indicating that transcription through the tel omere did not mask the activity of the Sir proteins (data not shown). As reduced recombination between $\mathrm{C}_{1-3} \mathrm{~A} / \mathrm{TG} \mathrm{G}_{1-3}$ tracts did not require Sir proteins, the telomere's effect on recombination of $\mathrm{C}_{1-3} \mathrm{~A} / \mathrm{TG}_{1-3}$ tracts is not under the same genetic control as the position effects that cause transcriptional repression at telomeres (A paricio et al. 1991) or at internal tracts of $\mathrm{C}_{1-3} \mathrm{~A} / \mathrm{TG}_{1-3}$ DNA (Stavenhagen and Zakian 1994).

The effect of hprls on recombination between tracts of $\mathrm{C}_{1-3} \mathrm{~A} / \mathrm{TG}_{1-3} \mathrm{DNA}$

Lack of Hprlp is associated with a large increase in direct-repeat recombination but has little or no effect on gene conversion or reciprocal exchange (Aguilera and Klein 1989). Using direct-repeat assay systems based on either 2.16- or $0.75-\mathrm{kb}$ tracts of unique sequence DN A, the rate of excision events increases 950- and 270-fold, respectively, in an hprls strain (Santos-Rosa and Aguilera 1994). To determine whether Hprlp is involved in the repression of recombination between $\mathrm{C}_{1-3} \mathrm{~A} / \mathrm{TG}_{1-3}$ tracts near a telomere, HPR 1 was del eted in strains with the $C_{1-3} A / T G_{1-3}$ recombination substrate or the control substrates at 5 and $20 \mathrm{~kb}$ from the chromosome VII-L telomere, and the rate of generating $\mathrm{FOA}^{\mathrm{R}} \mathrm{Lys}^{+}$colonies was measured in each strain (Fig. 4).

Recombination of all three substrates at both 5 and 20 $\mathrm{kb}$ from the telomere was increased in an hprls back- 


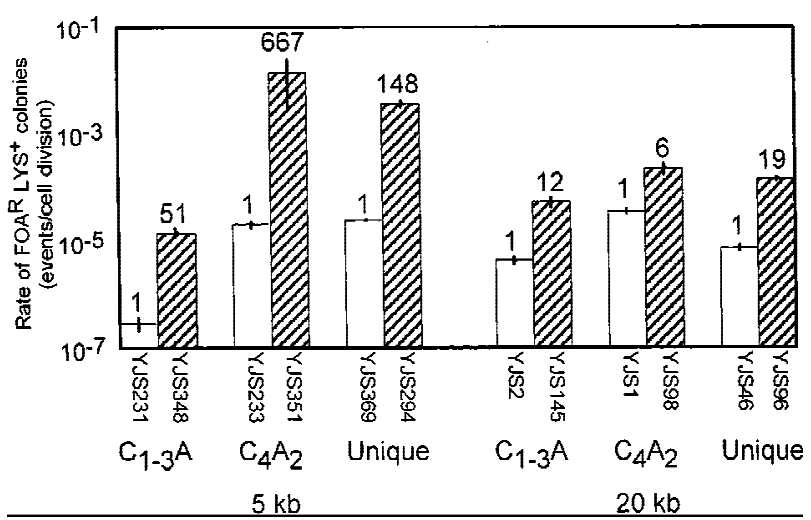

Figure 4. Rates of recombination in an hprls strain. Rates of recombination were determined for wild-type (open bars) and hprls (hatched bars) versions of the same strain with the recombination substrate located either 5 (left) or 20 (right) kb from the chromosome VII-L telomere (see Materials and M ethods). Interpretation of the graph is the same as in Fig. 2A, however the scale for the $y$-axis is different than in preceding figures. The numbers above the columns represent the fold difference in recombination rate for the same substrate relative to the wildtype strain at the same location. The rates for direct repeat recombination in hprl $\Delta$ strains $5 \mathrm{~kb}$ from the telomere are $1.5 \times 10^{-5}( \pm 0.2)$ events/cell division, $1.4 \times 10^{-2}( \pm 1.1)$ events/ cell division, and $3.7 \times 10^{-3}( \pm 0.5)$ events/cell division for $\mathrm{C}_{1-3} \mathrm{~A} / \mathrm{TG}_{1-3}, \mathrm{C}_{4} \mathrm{~A}_{2} / \mathrm{T}_{2} \mathrm{G}_{4}$, and unique sequence, respectively. The rates for direct repeat recombination in hprl $\Delta$ strains $20 \mathrm{~kb}$ from the telomere are $5.3 \times 10^{-5}( \pm 1.1)$ events/cell division, $2.2 \times 10^{-4}( \pm 0.5)$ events/cell division, and $1.4 \times 10^{-4}( \pm 0.1)$ events/cell division for $\mathrm{C}_{1-3} \mathrm{~A} / \mathrm{TG}_{1-3}, \mathrm{C}_{4} \mathrm{~A}_{2} / \mathrm{T}_{2} \mathrm{G}_{4}$, and Unique sequence, respectively.

ground compared to the recombination rate of the same substrate at the same location in a wild-type cell (Fig. 4). However, for all three substrates, the increase was more dramatic near the telomere than at $20 \mathrm{~kb}$ from the telomere. This difference was especially marked for the two control substrates. For example, compared to wild-type, recombination of the unique sequence substrate in the hprls strain was increased 148-fold near the telomere but only $19-$ fold at $20 \mathrm{~kb}$. The difference was even more dramatic for the $\mathrm{C}_{4} \mathrm{~A}_{2} / \mathrm{T}_{2} \mathrm{G}_{4}$ direct repeats, which showed an $\sim 670$-fold difference at $5 \mathrm{~kb}$ but only a sixfold difference at $20 \mathrm{~kb}$. As a consequence, in the hprls strain, both control substrates recombined at a much higher rate near the tel omere than at $20 \mathrm{~kb}$. This result is the first unequivocal example of $\mathrm{Hprlp}$ having markedly different effects on recombination rates as a function of the substrate's position within the genome. Thus, the magnitude of Hprl's effect on recombination can be influenced profoundly by both the sequence and the chromosomal context of the recombining DNA.

Like the two control substrates, the recombination rate between $\mathrm{C}_{1-3} \mathrm{~A} / \mathrm{TG}_{1-3}$ tracts at both 5 and $20 \mathrm{~kb}$ from the telomere was higher in the $h p r l \Delta$ strain than in wild-type cells (51- and 12-fold elevations, respectively; Fig. 4). Because the rate of recombination between $\mathrm{C}_{1-3} \mathrm{~A} / \mathrm{TG}_{1-3}$ tracts was increased to a greater extent near the tel omere, recombi nation between $C_{1-3} A / T G_{1-3}$ tracts occurred at roughly similar rates at 5 and $20 \mathrm{~kb}$ from the telomere in the hpr $1 \Delta$ strain (threefold higher rate at $20 \mathrm{~kb}$ in the hprl$\Delta \Delta$ strain vs. 15-fold in wild type, Fig. 4). However, in the hpr $1 \Delta$ strain, recombination near the telomere was still much less frequent between $\mathrm{C}_{1-3} \mathrm{~A} / \mathrm{TG}_{1-3}$ tracts than between the control tracts, occurring at rates that were $\sim 250$ (unique)- or $\sim 900\left(C_{4} A_{2} /\right.$ $\mathrm{G}_{4} \mathrm{~T}_{2}$ )-fold lower than the controls at the same site. Thus, although $\mathrm{Hprlp}$ reduced recombination of all three substrates at both chromosomal sites, it was not responsible for the sequence-specific reduction in recombi nation between $\mathrm{C}_{1-3} \mathrm{~A} / \mathrm{TG}_{1-3}$ tracts near the tel omere. Rather, this position effect was exacerbated in hprls cells.

Recombination between $\mathrm{C}_{1-3} \mathrm{~A} / \mathrm{TG}_{1-3}$ tracts near the telomere is RAD52-independent

Recombination between direct repeats resulting in the excision of intervening DNA can occur by different recombination pathways (for review, see Klein 1995). For example, a pop-out deletion event can proceed via a RAD52-dependent pathway, involving parallel alignment of the direct repeats on the same chromosome, followed by a crossover event (Petes et al. 1991). Singlestrand annealing (SSA), an alternative nonconservative pathway for recombination between direct repeats which, like pop-out events, eliminates the DNA between the repeats, is RAD1 dependent (Lin et al. 1984; Fishman-Lobell et al. 1992). SSA events between naturally occurring tandem repeats such as those found at the rDN A are RAD52 independent (Zamb and Petes 1981). To begin to understand the mechanism of recombination between di rect repeats near the tel omere, recombination between the $\mathrm{C}_{1-3} \mathrm{~A} / \mathrm{TG}_{1-3}$ tracts and the control substrates was studied in rad $1 \Delta, \operatorname{rad} 52 \Delta$, and $\operatorname{rad} 1 \Delta$ rad52 $\Delta$ strains either at 5 or $20 \mathrm{~kb}$ from the telomere on chromosome VII-L (Table 2).

At $5 \mathrm{~kb}$ from the tel omere, recombination of the control substrates occurred al most exclusively by a RAD52dependent pathway ( $T$ able 2 ). In contrast, the few recombination events that occurred between the $C_{1-3} A / T G_{1-3}$ tracts $5 \mathrm{~kb}$ from the telomere were not el iminated in the rad $52 \Delta$ strain but rather were RAD 1 dependent. At $20 \mathrm{~kb}$ from the telomere, as at $5 \mathrm{~kb}$, recombination between the unique sequence tracts was RAD 52 dependent. However, for both the $C_{1-3} A / T G_{1-3}$ and $C_{4} A_{2} / T_{2} G_{4}$ substrates $20 \mathrm{~kb}$ from the telomere, recombination was reduced substantially but not eliminated in both the rad $52 \Delta$ and rad $1 \Delta$ strains. Thus, for these internal ly repetiti ous substrates at $20 \mathrm{~kb}$ from the telomere, both pathways contributed to the observed rate of recombination. The level of recombination between $C_{1-3} A / T G_{1-3}$ tracts at both 5 and $20 \mathrm{~kb}$ from the telomere was below the limits of detection in the rad $1 \Delta$ rad52 $\Delta$ strain, suggesting that Rad52p- and Rad1p-dependent recombination accounted for virtually all recombination events. This result also confirmed that recombination was the predominant mode for generating FOA ${ }^{\mathrm{R}}$ col onies in this system. Taken together, these data suggest that the rarity of 
Table 2. Effects of RAD52 and RAD1 on recombination between direct repeats

\begin{tabular}{|c|c|c|c|c|c|}
\hline Strain & $\begin{array}{l}\text { Distance from } \\
\text { telomere (kb) }\end{array}$ & $\begin{array}{c}\text { Tract } \\
\text { sequence }\end{array}$ & RAD allele & Rate (S.D.) ${ }^{a}$ & $\operatorname{rad} \Delta /$ RAD \\
\hline YJS231 & 5 & $\mathrm{C}_{1-3} \mathrm{~A} / \mathrm{TG}_{1-3}$ & wild type & $2.9 \times 10^{-7}( \pm 0.80)$ & - \\
\hline YJS288 & 5 & $\mathrm{C}_{1-3} \mathrm{~A} / \mathrm{TG}_{1-3}$ & $\operatorname{rad} 52 \Delta$ & $3.0 \times 10^{-7}( \pm 0.68)$ & 1.0 \\
\hline YJS393 & 5 & $\mathrm{C}_{1-3} \mathrm{~A} / \mathrm{TG}_{1-3}$ & $\operatorname{rad} 1 \Delta$ & $1.8 \times 10^{-8}( \pm 0.75)$ & 0.06 \\
\hline YJS399 & 5 & $\mathrm{C}_{1-3} \mathrm{~A} / \mathrm{TG}_{1-3}$ & $\operatorname{rad} 52 \Delta \operatorname{rad} 1 \Delta$ & $<1.8 \times 10^{-8 *}$ & $\varangle 0.06$ \\
\hline YJS233 & 5 & $\mathrm{C}_{4} \mathrm{~A}_{2} / \mathrm{T}_{2} \mathrm{G}_{4}$ & wild type & $2.1 \times 10^{-5}( \pm 0.30)$ & - \\
\hline YJS290 & 5 & $\mathrm{C}_{4} \mathrm{~A}_{2} / \mathrm{T}_{2} \mathrm{G}_{4}$ & $\operatorname{rad} 52 \Delta$ & $2.6 \times 10^{-6}( \pm 0.66)$ & 0.1 \\
\hline YJS392 & 5 & $\mathrm{C}_{4} \mathrm{~A}_{2} / \mathrm{T}_{2} \mathrm{G}_{4}$ & $\operatorname{rad} 1 \Delta$ & $1.2 \times 10^{-5}( \pm 0.17)$ & 0.6 \\
\hline YJS369 & 5 & unique & wild type & $2.5 \times 10^{-5}( \pm 0.20)$ & - \\
\hline YJS292 & 5 & unique & $\operatorname{rad} 52 \Delta$ & $<1.0 \times 10^{-7}$ & $\triangleleft 0.01$ \\
\hline YJS2 & 20 & $\mathrm{C}_{1-3} \mathrm{~A} / \mathrm{TG}_{1-3}$ & wild type & $4.4 \times 10^{-6}( \pm 0.70)$ & - \\
\hline YJS142 & 20 & $\mathrm{C}_{1-3} \mathrm{~A} / \mathrm{TG}_{1-3}$ & $\operatorname{rad} 52 \Delta$ & $1.7 \times 10^{-6}( \pm 0.42)$ & 0.4 \\
\hline YJS146 & 20 & $\mathrm{C}_{1-3} \mathrm{~A} / \mathrm{TG}_{1-3}$ & $\operatorname{rad} 1 \Delta$ & $9.0 \times 10^{-7}( \pm 2.40)$ & 0.2 \\
\hline YJS402 & 20 & $\mathrm{C}_{1-3} \mathrm{~A} / \mathrm{TG}_{1-3}$ & $\operatorname{rad} 52 \Delta \operatorname{rad} 1 \Delta$ & $<1.0 \times 10^{-7 *}$ & $\varangle 0.02$ \\
\hline YJS1 & 20 & $\mathrm{C}_{4} \mathrm{~A}_{2} / \mathrm{T}_{2} \mathrm{G}_{4}$ & wild type & $3.6 \times 10^{-5}( \pm 0.30)$ & - \\
\hline YJS90 & 20 & $\mathrm{C}_{4} \mathrm{~A}_{2} / \mathrm{T}_{2} \mathrm{G}_{4}$ & $\operatorname{rad} 52 \Delta$ & $1.6 \times 10^{-5}( \pm 0.18)$ & 0.4 \\
\hline YJS390 & 20 & $\mathrm{C}_{4} \mathrm{~A}_{2} / \mathrm{T}_{2} \mathrm{G}_{4}$ & $\operatorname{rad} 1 \Delta$ & $5.8 \times 10^{-6}( \pm 1.10)$ & 0.16 \\
\hline YJS46 & 20 & unique & wild type & $7.3 \times 10^{-6}( \pm 1.00)$ & - \\
\hline YJS88 & 20 & unique & rad52s & $3.5 \times 10^{-7}( \pm 1.10)$ & 0.05 \\
\hline
\end{tabular}

The rate of $\mathrm{FOA}^{\mathrm{R}} \mathrm{Lys}^{+}$colonies was measured and calculated as described in M aterials and $\mathrm{M}$ ethods.

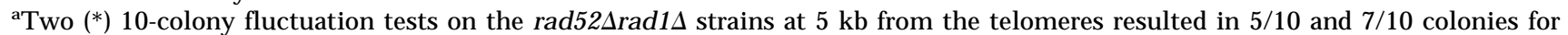
which 0 recombination events were recovered. Similarly for rad52rad1 strains $20 \mathrm{~kb}$ from the telomere fluctuation assays resulted in $7 / 10$ and $3 / 10$ colonies in which 0 recombination events were recovered. These fluctuation tests resulted in a median val ue of zero and are shown as rates less than a maximum value.

recombination between $\mathrm{C}_{1-3} \mathrm{~A} / \mathrm{TG}_{1-3}$ tracts near the telomere is explained in large part by the absence of RAD52-dependent events, either because these events did not occur or because they could not be recovered near the telomere. However, RAD1-mediated recombination events were also repressed $\sim 10$-fold near the telomere (compare recombination rate for $\mathrm{C}_{1-3} \mathrm{~A} / \mathrm{TG}_{1-3}$ tracts and $\mathrm{C}_{4} \mathrm{~A}_{2} / \mathrm{T}_{2} \mathrm{G}_{4}$ tracts near the telomere in the rad52 $\Delta$ strains; Table 2).

\section{The effect of RAP1 on $\mathrm{C}_{1-3} \mathrm{~A}$ direct-repeat recombination}

Raplp, the major telomere-binding protein in yeast, or proteins that bind to the telomere via interactions with Raplp are excellent candidates for restricting the access of tel omeric sequences to recombination enzymes. Since RAP1 is an essential gene, it was not possible to determine the effects of eliminating Raplp on recombination. As an alternative approach, high levels of Raplp were expressed by introduction of a high copy plasmid harboring the RAP1 gene, FATRAP, into the appropriate strains. As determined previously, cells carrying this plasmid have 3-5 times more Raplp than wild-type cells, have longer and more heterogeneous length telomeres, and show el evated rates of chromosome loss and mitotic recombination at nontel omeric sites (Conrad et al . 1990). If Raplp were limiting for recombination between $\mathrm{C}_{1-3} \mathrm{~A} / \mathrm{TG}_{1-3}$ tracts near the telomere, in the simplest model, this recombination might be reduced even further in cells overexpressing Raplp.

The FATRAP plasmid was introduced into strains carrying either $\mathrm{C}_{1-3} \mathrm{~A} / \mathrm{TG}_{1-3}$ or $\mathrm{C}_{4} \mathrm{~A}_{2} / \mathrm{T}_{2} \mathrm{G}_{4}$ tracts at both 5 and $20 \mathrm{~kb}$ from the telomere of chromosome VII-L. The presence of theFATRAP plasmid had no effect on recombination in control strains (Fig. 5A). However, its presence led to a dramatic increase in the generation of FOA ${ }^{R}$ Lys $^{+}$colonies in both strains with $\mathrm{C}_{1-3} \mathrm{~A} / \mathrm{TG}_{1-3}$ tracts (Fig. 5A). Recombination rates were increased 146-fold at $5 \mathrm{~kb}$ and 841 -fold at $20 \mathrm{~kb}$ such that recombination between the $\mathrm{C}_{1-3} \mathrm{~A} / \mathrm{TG}_{1-3}$ tracts was either comparable (at $5 \mathrm{~kb}$ ) or greater (at $20 \mathrm{~kb}$ ) than recombination between the control tracts at the same locus. A control plasmid carrying an out-of-frame deletion derivative of the RAP1 gene, FATRAP $\triangle B B F$ (Conrad et al. 1990), did not affect recombination rates in any of the strains, demonstrating that the effects were caused by expression of Raplp (data not shown).

It had been proposed previously that the increase in heterogeneity of telomere length associated with excess Raplp might be the result of interchromosomal recombination between telomeric and/or internal tracts of telomeric DNA (Conrad et al. 1990). As inferred from structural analysis (Table 1), interchromosomal recombination was not detected in wild-type or mutant cells. To determine whether interchromosomal recombination occurred in the presence of excess Raplp, Southern bl ot anal ysis was used to determine the structure of recombinant chromosomes in independent FOA ${ }^{\mathrm{R}}$ Lys $^{+}$colonies derived from strains containing the FATRAP plasmid (Fig. 5C,D). As described earlier, both intrachromosomal recombination and sister chromatid exchange produce a Bglll fragment that will hybridize to both the A (LYS2) and the B (ADH4) probes. In contrast, interchromosomal recombination will transfer LYS2 to another chromosome such that the A and 
A

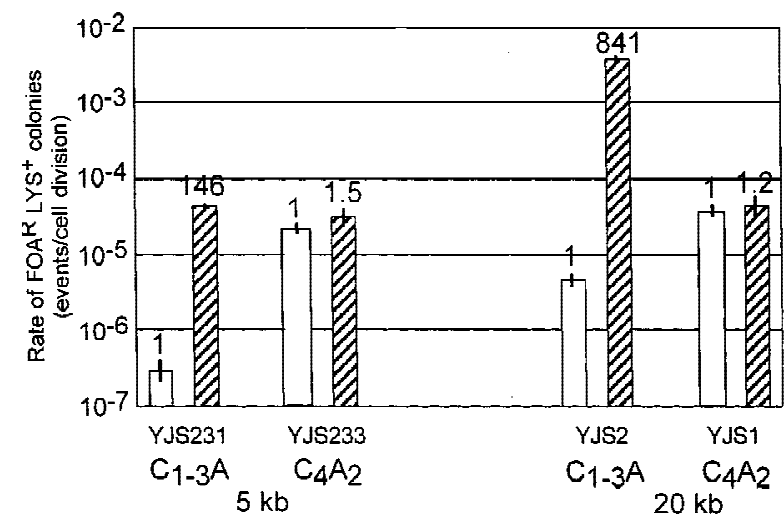

B

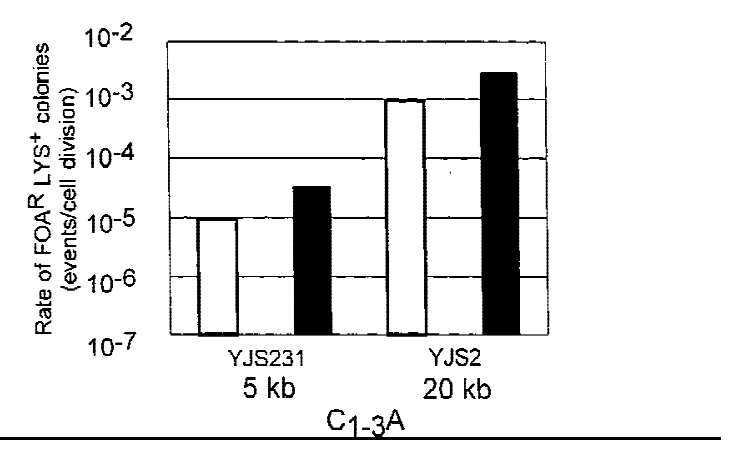

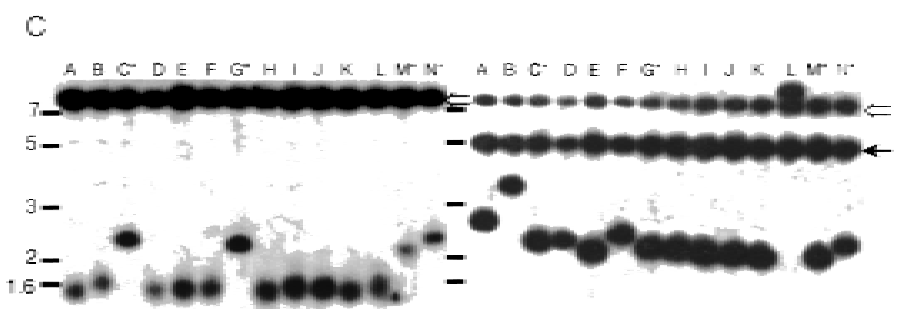

Probe: $A D H 4$ Y.JS231

Probe: LYSe

D

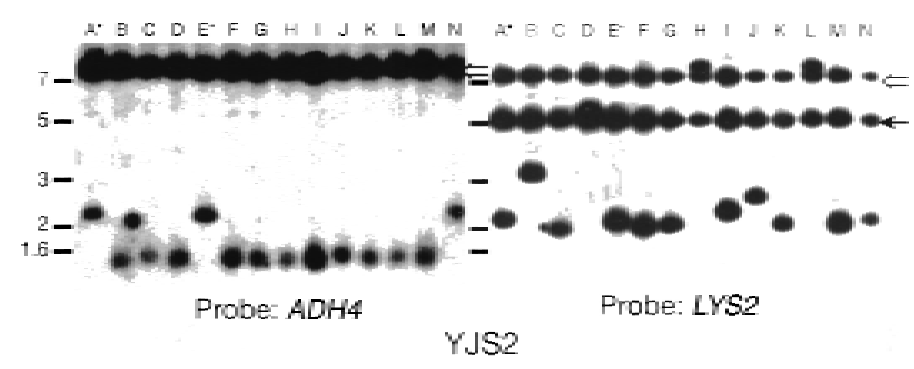

Figure 5. Recombination in strains overexpressing Raplp. (A) Rates of recombination between direct repeats in strains over expressing RAP1. Description of the graph is the same as in Fig. 3. The white columns represent the values for strains with wild-type levels of Raplp and the striped columns represent cells containing FATRAP, which express high levels of Raplp. (B) The rates of excision or interchromosomal $\mathrm{C}_{1-3} \mathrm{~A} / \mathrm{TG}_{1-3}$ direct-repeat recombination events at 5 and $20 \mathrm{~kb}$ from the tel omere are depicted separately. (Open bars) Excision events; (solid bars) interchromosomal events. The different events were determined by Southern analysis (see bel ow). (C) Southern analysis of FOA ${ }^{\text {Lys }}{ }^{+}$events from YJS231 (tract $5 \mathrm{~kb}$ from chromosome VII-L tel omere) transformed with FATRAP (see Materials and Methods). Genomic DNA was digested with Bglll and run on a $1 \%$ agarose gel. Molecular mass standards (kb) are indicated at left. The probe is indicated at the bottom. The filter was first hybridized to the ADH4 (probe B), the probe was removed, and filters were then reprobed with LYS2 DN A (probe A). (Lanes A-N) Different independent recombination events. Hybridizing high molecular mass bands are caused by cross-hybridization of the probe to the FATRAP vector sequences (open arrow) and to the endogenous LYS2 gene (solid arrow). All other bands seen are products of the recombination reaction. Lanes marked with an asterisk have a 2.0-2.6 kb hybridizing band that hybridizes to both the LYS2 and ADH4 probes, indicative of an excision event. (D) Southern analysis of FOA ${ }^{R}$ Lys $^{+}$events from YJS2 (tracts $20 \mathrm{~kb}$ from chromosome VII-L telomere) transformed with FATRAP. Symbols are the same as in $C$.

B probes hybridize to different-sized restriction fragments.

In $21 \%$ and $26 \%$ of the FOA ${ }^{\mathrm{R}} \mathrm{Lys}^{+}$colonies examined at 5 and $20 \mathrm{~kb}$, respectively, the predicted product for an excision event was observed (Fig. 5C,D; data not shown; summarized in Fig. 5B). In the remaining recombinants, interchromosomal recombination occurred as inferred from the hybridization of the A probe to different-sized bands on the Southern bl ot (Fig. 5C,D). Furthermore, in each of these samples the $B$ probe hybridized to $a \sim 1.5-\mathrm{kb}$ band, the expected size of a terminal restriction fragment if de novo telomere formation occurred at the proximal $\mathrm{C}_{1-3} \mathrm{~A} / \mathrm{TG}_{1-3}$ tract on chromosome VII-L. In one sample (lane $M$, Fig. 5C), a mixed population of cells was detected, containing both an ADH4 hybridizing terminal fragment and $a$ band that hybridized to both the $A$ and $B$ probes.

Pulsed-field gel analysis was done to confirm that the altered size of the LYS2 hybridizing fragments was caused by interchromosomal recombination. In the starting strain with the recombination substrate integrated $20 \mathrm{~kb}$ from the tel omere on chromosome VII-L, a LYS2 probe should hybridize to both chromosome VII and to chromosome II, the normal chromosomal Iocation of LYS2. As expected, seven of seven recombinants obtained in the wild-type strain had the structure expected for an excision event (i.e., LYS2 hybridized to both chromosomes VII and II; Fig. 6, Ianes A-G). In contrast, in 13 of 18 recombinants from cells expressing high levels of Rap1p, LYS2 did not hybridize to chromosome VII (Fig. 6, lanes H-Y). In 3 of 18 recombinants, LYS2 hybridized to a single chromosome, similar in size to chromosome II (Fig. 6, Ianes R, T, and Y). In two recombinants, LYS2 did not hybridize to chromosome VII but hybridized to two new chromosomes (in addition to 


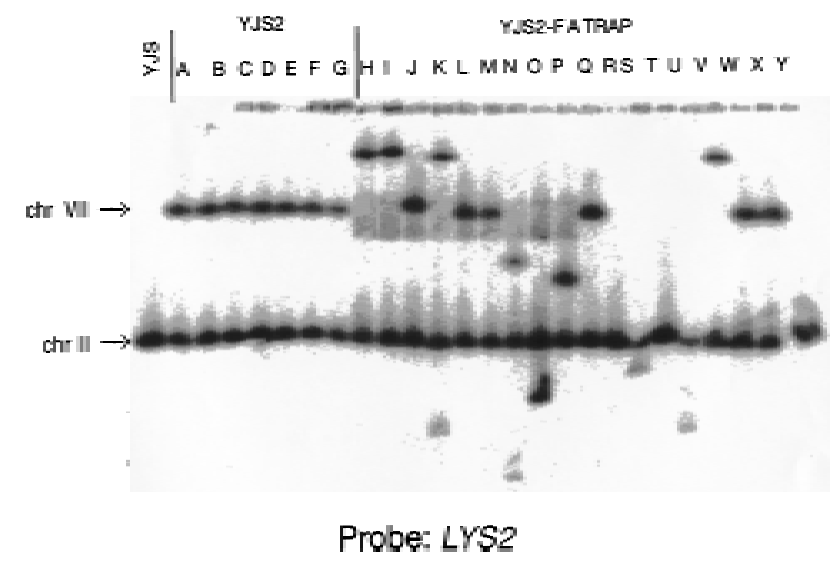

Figure 6. Analysis of chromosomes from $\mathrm{FOA}^{\mathrm{R}} \mathrm{LYS}^{+}$cells generated in the presence of excess Raplp. Chromosomes were isolated from the parent strain ( $Y J S$ ), a strain containing the $\mathrm{C}_{1-3} \mathrm{~A} / \mathrm{TG}_{1-3}$ direct repeat recombination assay $20 \mathrm{~kb}$ from the telomere on chromosome VII-L (YJS2) and the same strain expressing excess Raplp (YJS2-FATRAP) (see M aterials and M ethods). Chromosomes were separated using a 1.5\% agarose gel using a CHEF gel apparatus. The filter was hybridized with probe A. Chromosome II, which contains the endogenous LYS2 locus (chr II), and chromosome VII, where the LYS2 gene and $\mathrm{C}_{1-3} \mathrm{~A} / \mathrm{TG}_{1-3}$ direct repeats were integrated (chr $\mathrm{VII}$ ), are indicated.

chromosomell; Fig. 6, lanes K,N ), suggesting that recombination occurred after DN A replication. In eight recombinants, LYS2 hybridized to chromosome II and to a second chromosome other than chromosome VII (Fig. 6, Ianes $\mathrm{H}-\mathrm{J}, \mathrm{O}, \mathrm{P}, \mathrm{S}, \mathrm{U}, \mathrm{V}$ ).

In summary, Raplp overexpression virtually eliminated the sequence-specific repression of recombination between tracts of $\mathrm{C}_{1-3} \mathrm{~A} / \mathrm{TG}_{1-3} \mathrm{DNA}$ near the telomere, so far the only gene or condition found to do so. Overexpression of Raplp also greatly increased recombination between $\mathrm{C}_{1-3} \mathrm{~A} / \mathrm{TG}_{1-3}$ tracts at internal sites. As a consequence, in Raplp overexpressing cells, recombination between $\mathrm{C}_{1-3} \mathrm{~A} / \mathrm{TG}_{1-3}$ tracts at $20 \mathrm{~kb}$ was $\sim 25$-fold higher than the control at $20 \mathrm{~kb}$ and $\sim 90$-fold higher than for $\mathrm{C}_{1-3} \mathrm{~A} / \mathrm{TG}_{1-3}$ tracts near the tel omere.

\section{Discussion}

In this paper we show that recombination between tracts of $\mathrm{C}_{1-3} \mathrm{~A} / \mathrm{TG}_{1-3} \mathrm{DNA}$ was inhibited substantially when the tracts were near a telomere. This reduction was caused by both to an absence of RAD52-dependent recombination events and to a reduction in the number of RAD1-dependent events (Table 2). Inhibition was general, occurring at both $4 \mathrm{~kb}$ from the right telomere of chromosome $\mathrm{V}$ and at $5 \mathrm{~kb}$ from the left telomere of chromosome VII (Fig. 2). In contrast, the recombination rate for two control substrates was not affected by proximity to the telomere, occurring at essentially the same rate whether the tracts were $\sim 5, \sim 20$, or $\sim 200 \mathrm{~kb}$ from a telomere (Fig. 2). These results are consistent with an earlier study which found that the recombination rate between direct repeats of LEU 2 segments was not af- fected by proximity to the telomere (Prado and Aguilera 1995).

Intrachromosomal recombination between telomeric DNA is a mechanism for the rapid shortening of elongated telomeres (Li and Lustig 1996). Tel omere rapid deletion (TRD) events occur at a high rate in yeast cells containing abnormally long telomeres ( $\mathrm{Li}$ and Lustig 1996). TRD events are repressed 10 -fold by H prlp ( $\mathrm{Li}$ and Lustig 1996), si milar to the events detected in this study (Fig. 4). Unlike recombination events between $\mathrm{C}_{1-3} \mathrm{~A} /$ $T_{G_{1-3}}$ direct repeats, TRD events are regulated negatively by SIR3 and are RAD 1-independent ( $\mathrm{Li}$ and Lustig 1996). TRD has been proposed as a mechanism for maintaining tel omere length using nonhomol ogous tel omeres as a yardstick to determine how much tel omeric DN A to delete ( $\mathrm{Li}$ and Lustig 1996). The relationship between TRD and $\mathrm{C}_{1-3} \mathrm{~A} / \mathrm{TG}_{1-3}$ direct-repeat recombination is unclear with regard to both the initiation of these events and the exact pathway of recombination.

In mitotic yeast cells, tel omere-adjacent DNA is both transcriptionally repressed and late replicating (for review, see Zakian 1996). Given these data, it is not surprising that telomeres affect mitotic recombination rates. However, position effects on transcription, replication, and recombination typically act on most nearby DNA. In contrast, the reduced mitotic recombination near yeast telomeres was seen only for recombination between $\mathrm{C}_{1-3} \mathrm{~A} / \mathrm{TG}_{1-3}$ tracts. M oreover, this position effect did not depend on Sir proteins (Fig. 3), which are essential for transcriptional silencing at telomeres (A paricio et al. 1991). In yeast meiosis, double-strand breaks (DSBs), which are thought to initiate recombination, are rare near telomeres (Klein et al. 1996; Baudat and Nicolas 1997). Lack of Sir4p does not increase the number of DSBs near telomeres in meiosis (Baudat and $\mathrm{N}$ icolas 1997), suggesting that the DSB-resistant nature of subtelomeric DNA is al so not mediated by the factors that are responsible for the closed chromatin structure associated with TPE. Any model to explain the reduction in mitotic recombination near telomeres must explain why this effect is sequence specific.

The yeast telosome is comprised of the duplex DNAbinding protein Raplp, the single-strand $\mathrm{TG}_{1-3}$ binding protein Cdc13p, and at least five other proteins, Sir2p, Sir3p, Sir4p, Rif1p, and Rif2p, that associate with the telomere via protein-protein interactions (Bourns et al. 1998). $\mathrm{N}$ one of the tel osomal proteins is expected to bind either of the two control substrates. We propose that internal tracts of $\mathrm{C}_{1-3} \mathrm{~A} / \mathrm{TG}_{1-3} \mathrm{DNA}$, like telomeres themselves (Wright et al. 1992), can adopt a Raplp-me diated tel osomelike chromatin structure. This proposal is supported by the demonstration that Raplp, Sir proteins, and Rif proteins bind internal tracts of $\mathrm{C}_{1-3} \mathrm{~A}$ / $\mathrm{TG}_{1-3}$ DN A (Bourns et al. 1998) as well as by the ability of these tracts to act as Raplp-dependent transcriptional silencers (Stavenhagen and Zakian 1994). We further hypothesize that the internal tracts are more likely to form this non-nucleosomal chromatin structure when they are near a telomere. This prediction is supported by the demonstration that the silencing activity of internal 
$\mathrm{C}_{1-3} \mathrm{~A} / \mathrm{TG}_{1-3}$ tracts increases as the tracts get closer to a telomere (Stavenhagen and Zakian 1994). According to this model, the telosome-like chromatin structure inhibits the generation or processing of recombination intermediates. Regional differences in chromatin structure have also been proposed to affect HO-endonuclease-induced recombination and nucleotide excision repair at the silent mating type loci (Verhage et al . 1994; Sugawara et al. 1995).

Raplp is the main telomere-binding protein in yeast and as such is present at high concentrations at natural telomeres (see Introduction). High levels of Raplp increased dramatically recombination between tracts of $\mathrm{C}_{1-3} \mathrm{~A} / \mathrm{TG}_{1-3}$ near the tel omere and resulted in high levels of interchromosomal recombination. The identification of different recombination products suggests that, in the presence of excess Raplp, internal tracts of tel omeric DN A may recombine via multiple recombination pathways. In addition, high levels of Raplp eliminated the sequence-specific repression of recombination between $\mathrm{C}_{1-3} \mathrm{~A} / \mathrm{TG}_{1-3}$ tracts near the tel omere (Fig. 5). The effects of Raplp on recombination between $C_{1-3} A / T G_{1-3}$ tracts were not caused by a global effect on recombination as the recombination rates of the control substrates were not affected (Fig. 5A).

Why does excess Raplp eliminate the sequence-specific effect of the telomere on recombination? One possibility is that excess Raplp disrupts the normal telosome structure and prevents the telomere from blocking recombination. Alternatively, the recombination inhibitor might be a Raplp-interacting protein that is titrated from the telomere by excess Raplp. This model is argued against by the fact that elimination of the Raplp-interacting Sir proteins resulted in even lower rates of recombination (Fig. 3). Moreover, elimination of both Rif1p and Rif2p, two Raplp-interacting proteins that act synergistically to restrict telomere length (Wotton and Shore 1997), led to a modest threefold increase in $\mathrm{C}_{1-3} \mathrm{~A} / \mathrm{TG}_{1-3}$ recombination near the telomere (J.B. Stavenhagen, unpubl.).

Another possibility is that proteins that bind to the very end of the chromosome might inhibit recombination between $\mathrm{C}_{1-3} \mathrm{~A} / \mathrm{TG}_{1-3}$ tracts. One candi date is the yeast homolog of mammalian Ku proteins, a heterodimer in which one subunit is encoded by HDF1 (Feldmann and Winnacker 1993) and the other by YKU 80/ HDF2 (Boulton and Jackson 1996). Hdf2p binds telomeres in vivo (Gravel et al. 1998), whereas the absence of $\mathrm{Ku}$ proteins disrupts the subnuclear positioning of telomeres (Laroche et al. 1998) and increases the intratelomeric recombination (Polotnianka et al. 1988) that results in rapid shortening of long tel omeres ( $\mathrm{Li}$ and Lustig 1996). Because Sir4p associates with Hdflp in vivo (Tsukamoto et al. 1997), eliminating Sir proteins might increase the amount of Hdflp available for telomere binding.

Y et another possibility is that the single-strand $\mathrm{TG}_{1-3}$ binding protein $\mathrm{Cdc} 13 \mathrm{p}$ inhibits recombination between $\mathrm{C}_{1-3} \mathrm{~A} / \mathrm{TG}_{1-3}$ tracts. A 3 '-single-stranded tail generated by a $5^{\prime}-3^{\prime}$-exonuclease is thought to be an intermediate in both the RAD 1-dependent SSA and RAD 52-dependent models of recombination (White and Haber 1990; Ozenberger and Roeder 1991; Fishman-Lobell et al. 1992). If a break occurs between two $\mathrm{C}_{1-3} \mathrm{~A}_{/} \mathrm{TG}_{1-3}$ tracts at any chromosomal locus, processing of this break by a $5^{\prime}-3^{\prime}-$ exonuclease will produce a molecule with a $3^{\prime}$ singlestranded $\mathrm{TG}_{1-3}$-tail. It is thought that RAD 52 interacts with a single-stranded DN A intermediate via the singlestranded DNA-binding protein Rfalp (Firmenich et al. 1995). Cdc13p might compete with Rfalp for binding, and its binding would block Rfalp-enhanced recombination. As the binding of Cdc13p is telomere limited in vivo (Bourns et al. 1998), the probability of a processed internal $\mathrm{C}_{1-3} \mathrm{~A} / \mathrm{TG}_{1-3}$ tract binding $\mathrm{Cdc} 13 \mathrm{p}$ is expected to increase and recombination to decrease with proximity to the telomere.

What is the rel evance of these data to telomere behavior on normal chromosomes? It is easy to imagine that the telomeric recombination inhibitor would also prevent recombination between natural telomeres in wildtype cells. For example, if Cdc13p or a Rif protein is the inhibitor and if its presence al so prevents recombination between chromosomal telomeres, it would explain why telomeres are longer in cells limited for these proteins (Hardy et al. 1992; Grandin et al. 1997; Wotton and Shore 1997). Because telomere-telomere recombination might occasional ly generate tel omere-tel omere fusi ons, inhi bition of this recombination in wild-type cells might reduce the generation of dicentric chromosomes. However, telomere-telomere recombination might be advantageous when telomeres are short, providing a telomerase-independent mechanism of telomere lengthening. If the recombination inhibitor has reduced affinity for short telomeres, its absence might promote RAD52-dependent recombination between $\mathrm{C}_{1-3} \mathrm{~A} / \mathrm{TG}_{1-3}$ tracts. This type of process could explain the presence and RAD52 dependency of terminal tracts of tel omeric DN A in cells that lack telomerase (Lundblad and Blackburn 1993); Singer and Gottschling 1994; McEachern and Blackburn 1995). If this model is correct, mutations that specifically increase recombination between $\mathrm{C}_{1-3} \mathrm{~A}$ / $\mathrm{TG}_{1-3}$ tracts near the tel omere might identify gene products important for a recombination pathway for maintenance of telomeric DNA.

\section{Materials and methods}

Yeast manipulations

M edia and plates for growth of yeast were made using standard procedures. Both liquid and solid media growth were carried out at $30^{\circ} \mathrm{C}$. Transformations were done by LiAC transformation (Stavenhagen and Zakian 1994). Y east strains were sporulated in $0.5 \% \mathrm{KoAc}$ at room temperature. Tetrad dissection was performed using a Singer dissection apparatus. For all dissected tetrads, strains were derived from four spore tetrads that showed the expected 2:2 segregation pattern.

Construction of direct-repeat recombination strains

The plasmids pYPVN, pTPV, and pUSR were used to integrate $\mathrm{C}_{1-3} \mathrm{~A} / \mathrm{TG}_{1-3}, \mathrm{C}_{4} \mathrm{~A}_{2} / \mathrm{T}_{2} \mathrm{G}_{4}$, or unique sequence tracts, $\sim 20 \mathrm{~kb}$ 
from the telomere on chromosome VII-L to construct strains YJS2, YJS1, and YJS46, respectively (Stavenhagen and Zakian 1994; Table 3). Plasmid pUSR was constructed by digesting pYPV-TPV-LYS with BgllI. The resulting 5.5-kb fragment was digested subsequently with $\mathrm{BamHI}$ and then ligated to the other 6-kb Bglll fragment to create plasmid pPV-Dis. Plasmid pPVDis was cut with EcoRI and blunt-ended with Klenow. A HinclI-EcoRV fragment from the tetracycline resistance (TC) gene of pBR322 was cl oned into this site to create a 276-bp direct repeat with a sequence from the Tc gene al ready present in the plasmid. To integrate $\mathrm{C}_{1-3} \mathrm{~A} / \mathrm{TG}_{1-3}$ tracts on chromosome VII-L, 5 $\mathrm{kb}$ from the telomere (YJS231), pYPVN was digested with SmalSall and gel isolated. A HindllI-Pvull fragment containing an 81-bp yeast telomeric tract from pTCA-1X was ligated to the
Smal-Sal I fragment and the resulting fragment was used to transform strain YJS5 (Stavenhagen and Zakian 1994). Integration of $\mathrm{C}_{4} \mathrm{~A}_{2} \mathrm{~T}_{2} \mathrm{G}_{4}$ tracts at the same locus (YJS233) was carried out with plasmid pTPV, using the same protocol. The resultant fragment was used to transform YJS4 (Stavenhagen and Zakian 1994). For integration of USR, $5 \mathrm{~kb}$ from the telomere at VII-L (YJS369), a single FOA ${ }^{R}$ Lys $^{+}$colony from YJS233 was transformed with an $\mathrm{Hpal}$ fragment from pUSR to generate a $\mathrm{U} \mathrm{ra}^{+} \mathrm{Lys}^{+}$cell. To integrate the direct repeat substrates $200 \mathrm{~kb}$ from the tel omere on chromosome VII-L, a 2.4-kb Clal fragment flanking LYS5 from plasmid pSC5 (Rajnarayan et al. 1992) was cut with Xbal and ligated into the Xbal site of pYPVN or cut with EcoRI and ligated into the EcoRI site of PTPVN. The resulting plasmids were linearized with Clal and used to trans-

Table 3. Summary of strains

\begin{tabular}{|c|c|c|}
\hline Strain & Genotype & Source \\
\hline YJS(YPH499) & MATa ura3-52 lys2-801 ade2-101 trp1- $\Delta 63$ his3- $\Delta 200$ leu2- $\Delta 1$ & Sikorski and Heiter (1989) \\
\hline YPH500 & MAT $\alpha$ version of YPH499 & Sikorski and Heiter (1989) \\
\hline YJS37 & YPH500; hpr1 $\Delta::$ HIS3 & this study \\
\hline YJS53 & YPH 500; rad52 $\Delta::$ LEU 2 & this study \\
\hline YJS110 & YPH $500 ; \operatorname{rad} 1 \Delta$ & this study \\
\hline YJS2 & YJS; adh4::pYPVN (20 kb from telomere VII-L) & Stavenhagen and Zakian (1994) \\
\hline YJS1 & YJS; adh4::pTPVN (20 kb from telomere VII-L) & Stavenhagen and Zakian (1994) \\
\hline YJS46 & YJS; adh4::pUSR (20 kb from telomere VII-L) & this study \\
\hline YJS231 & YJS; pYPVN-TEL-VIL-L (5 kb from telomere VII-L) & this study \\
\hline YJS233 & YJS; pTPVN-TEL-VIL-L (5 kb from telomere VII-L) & this study \\
\hline YJS369 & YJS; pUSR-TEL-VIL-L (5 kb from telomere VII-L) & this study \\
\hline YJS331 & YJS; Iys5:: pY PVN ( 200 kb from telomere VII-L) & this study \\
\hline YJS357 & YJS; Iys5::pT PVN ( 200 kb from telomere VII-L) & this study \\
\hline YJS367 & YJS; Iys5::pUSR ( 200 kb from telomere VII-L) & this study \\
\hline YJS335 & YJS; pYPVN-TEL-V-R (4 kb from telomere V-R) & this study \\
\hline YJS359 & YJS; pTPVN-TEL-V-R (4 kb from telomere V-R) & this study \\
\hline YJS365 & YJS; pUSR-TEL-V-R (4 kb from telomere V-R) & this study \\
\hline YJS329 & YJS; pYPVN-TEL-V-R (17 kb from telomere V-R) & this study \\
\hline YJS361 & YJS; pTPVN-TEL-V-R (17 kb from telomere V-R) & this study \\
\hline YJS371 & YJS; pUSR-TEL-V-R (17 kb from telomere V-R) & this study \\
\hline YJS602 & YJS; pYPVN-TEL-VII-L sir1::HIS3 & this study \\
\hline YJS333 & YJS; pYPVN-TEL-VII-L sir2::HIS3 & this study \\
\hline YJS334 & YJS; pYPVN-TEL-VII-L sir3::LEU 2 & this study \\
\hline YJS601 & YJS; pYPVN-TEL-VII-L sir4::HIS3 & this study \\
\hline YJS603 & YJS; pTPVN-TEL-VII-L sir1::HIS3 & this study \\
\hline YJS363 & YJS; pTPVN-TEL-VII-L sir2::HIS3 & this study \\
\hline YJS364 & YJS; pTPVN-TEL-VII-L sir3::LEU 2 & this study \\
\hline YJS600 & YJS; pTPVN-TEL-VII-L sir4::HIS3 & this study \\
\hline YJS348 & YJS; pYPVN-TEL-VII-L hpr1::HIS3 & this study \\
\hline YJS351 & YJS; pTPVN-TEL-VII-L hprl::HIS3 & this study \\
\hline YJS294 & MATa; YJS; pUSR-TEL-VII-L hpr1::HIS3 & this study \\
\hline YJS145 & YJS; adh4::pYPVN hpr1::HIS3 & this study \\
\hline YJS98 & YJS; adh4::pTPVN hpr1::HIS3 & this study \\
\hline YJS96 & YJS; adh4::pUSR hpr1::HIS3 & this study \\
\hline YJS288 & YJS; pYPVN-TEL-VII-L rad52::LEU 2 & this study \\
\hline YJS393 & YJS; pYPVN-TEL-VII-L radls & this study \\
\hline YJS399 & YJS; pYPVN-TEL-VII-L rad1rad52:: LEU 2 & this study \\
\hline YJS290 & YJS; pTPVN-TEL-VII-L rad52::LEU 2 & this study \\
\hline YJS392 & MATa; YJS; pTPVN-TEL-VII-L rad1 $\Delta$ & this study \\
\hline YJS292 & YJS; pUSR-TEL-VII-L rad52::LEU 2 & this study \\
\hline YJS147 & MATa; YJS; adh4:: pYPVN rad52::LEU 2 & this study \\
\hline YJS146 & YJS; adh4::pYPVN rad1s & this study \\
\hline YJS402 & MATa; YJS; adh4::pYPVN $\operatorname{rad} 1 \Delta \operatorname{rad} 52::$ LEU 2 & this study \\
\hline YJS90 & YJS; adh4:: pTPVN rad52::LEU 2 & this study \\
\hline YJS390 & YJS; adh4::pTPVN radls & this study \\
\hline YJS88 & YJS; adh4::pUSR rad52::LEU 2 & this study \\
\hline
\end{tabular}


form strain YPH499 (Sikorski and Hieter 1989), resulting in the strains YJS331 and YJS357, respectively. For YJS367 a single FOA $^{\mathrm{R}} \mathrm{Lys}^{+}$colony from YJS357 was transformed with a $\mathrm{Hpal}$ fragment from pUSR and a Ura'Lys ${ }^{+}$colony was selected. To integrate the $\mathrm{C}_{1-3} \mathrm{~A} / \mathrm{TG}_{1-3}$ direct repeats, $4 \mathrm{~kb}$ from the telomere on chromosome V-R (YJS335), a 2.8-kb fragment from plasmid B6-10H (Ferguson et al. 1991) was ligated into pYPVN . The resulting plasmid, pYPVN-VR-4, was digested with Pvull and ligated to the Pvull-Hindll fragment from pTCA-IX. The ligation reaction was digested with $\mathrm{Notl}$ and transformed into YPH499. For YJS365 and YJS359, a single FOA ${ }^{R}$ Lys $^{+}$colony from YJS335 was transformed with an $\mathrm{Hpal}$ fragment from pUSR and a EcoRI-H pal fragment from pTPV, respectively. For integration of the $\mathrm{C}_{1-3} \mathrm{~A} / \mathrm{TG}_{1-3}$ direct repeats, $\sim 17 \mathrm{~kb}$ from the $\mathrm{V}-\mathrm{R}$ telomere (YJS329), a 2.4-kb HindlII fragment from B6-10H was cut with Xbal and ligated into the Xbal site of pYPVN. The resulting plasmid, pYPVN-VR-17, was cut with HindIII and transformed into YPH499. For YJS371 and YJS361 a single FOA $^{R}$ Lys $^{+}$colony from YJS329 was transformed with a Hpal fragment from pUSR and a EcoRI-Hpal fragment from pTPV, respectively.

The YJS53 and YJS110 strains were made using the plasmids pSM 20 (rad52:LEU 2; gift of D. Schild, Lawrence Berkeley Laboratory, CA) and pLK23 (rad1) (Kadyk and Hartwell 1993), respectively. Initially, the mutations were made in strain YPH500 (Sikorski and Hieter 1989) by transformation and then mated into the appropriate direct repeat strain. For both rad52 $\Delta$ and $\operatorname{rad} 1 \Delta$ strains the correct transformants were first tested for UV sensitivity and then confirmed by genomic Southern analysis. After mating, diploids were sporulated. For $\operatorname{rad} 1 \Delta$, tetrads were dissected and spores showing U ra'Lys ${ }^{+}$and UV-sensitive phenotypes were selected for further analysis. Direct-repeat strains containing the rad52 $\Delta$ allele were derived from a random spore analysis by selection for $\mathrm{Ura}^{+} \mathrm{Lys}^{+} \mathrm{Leu}^{+}$spores. For the rad1 $\Delta$ rad52 $\Delta$ double mutants, tetrads were dissected and $\mathrm{Ura}^{+} \mathrm{Lys}^{+}$ $\mathrm{Leu}^{+}$spores were examined by genomic Southern analysis to determine if the rad $1 \Delta$ allele was present.

The sir $2 \Delta$, sir3 $\Delta$, and sir $4 \Delta$ strains were made using plasmids pJR531 (Kimmerly and Rine 1987), AR78 (Braunstein et al. 1993), and pMM 10.7 (gift of J. Broach, Princeton University) (Stavenhagen and Zakian 1994), respectively. For the sir $\Delta$ strains, transformants were verified by marker sel ection, loss of mating ability, and by genomic Southern analysis. Plasmid pABX4 (hpr1::HIS3 gift of H. Klein) (Aguilera and Klein 1989) was used to make YJS37 (hpr $1 \Delta$ ). The correct transformant was confirmed by genomic Southern analysis. YJS37 was mated to the direct repeat strains and $\mathrm{Ura}^{+} \mathrm{Lys}^{+} \mathrm{His}^{+}$spores were selected for further analysis. Both FATRAP and FATRAP $\triangle B B$ plasmids were described previously (Conrad et al. 1990).

\section{Recombination assays}

Recombination events were selected on medium containing FOA, which selects for loss of U RA 3 function, and lacking lysine, which selects for the presence of LYS2. The number of recombination events was indistinguishable for cells plated on medium lacking or containing lysine (data not shown). Rates were determined by fluctuation analysis (Luria and Delbruck 1943). All fluctuation assays were done using at least 10 independent colonies (20 colonies for analysis of wild-type rates for all three substrates at the five loci tested). For each strain two independent transformants were examined. Strains were grown on YC-Lys plates for 3-5 days. Individual colonies were isolated and picked as plugs into $0.5 \mathrm{ml}$ of $\mathrm{ddH}_{2} \mathrm{O}$. Aliquots from each colony were tested for the number of $\mathrm{FOA}^{\mathrm{R}} \mathrm{Lys}^{+}$colonies by spreading a fraction of the total colony onto plates lacking ly- sine and containing the drug 5-FOA (Boeke et al. 1987). The colonies that grew were replica plated subsequently to plates lacking uracil to ensure that $F A^{R}$ colonies were caused by recombination, not transcriptional silencing. $A$ second aliquot from each colony was pooled and serially diluted. A viable cell count was done by plating a fraction of the serial dilutions onto either YC or YC-Lys plates, depending on which media was used for the pregrowth prior to the fluctuation test. Rates and standard deviations were calculated using the method of the median (Lea and Coulson 1949) with the following modification. Standard deviations were determined using the average median rate, from a minimum of four assays, and adding all the colonies tested to obtain a value for total number of colonies. For each strain or condition, genomic Southern blot or PCR analysis was carried out on a subset of the FOA ${ }^{R}$ cells to establish that URA3 was eliminated. In some strains, the recombination rate was low enough that some FOA ${ }^{R}$ cells were caused by point mutation in URA3. In these cases, the FOA ${ }^{R}$ cells caused by mutation were eliminated from the calculation for the rate of recombination.

\section{DNA manipulations}

All restriction digests were done using standard protocols and enzymes ( $\mathrm{N}$ ew England Biolabs). Yeast DNA preparations and genomic Southern blots were done as described previously (Stavenhagen and Zakian 1994). Specifically, genomic DN A was digested with BglII and HindIII. The DNA was separated subsequently on a $1 \%$ agarose gel and transferred to nylon membrane (Amersham Hybond- $\mathrm{N}+$ ). The appropriate band was visualized by hybridization with a random primed Bglll-HindIII fragment from the $5^{\prime}$-end of the LYS2 gene. PCR reactions were done in a total volume of $10 \mu \mathrm{l}$ using Taq polymerase (Promega) in standard reaction buffer with the following modifications: 2 $\mathrm{mm} \mathrm{MgCl}_{2}, 200 \mathrm{~mm}$ dNTPs, $0.5 \mathrm{~mm}$ primers (JS04: 5'-GAA GATCTGGGTTAGTCAAATGGCAGGC-3' and JS05: 5'-CGGGATCCCTGGCAAAACTA TTGAAGAG-3'). A fraction of each yeast colony was picked using a plastic pi petman tip and placed at the bottom of the reaction tube into $5 \mu \mathrm{l}$ containing the primers. This was covered with an ampligem wax pellet (Perkin-Elmer). On top of the hardened wax was layered the remaining reaction ingredients. The cycling protocol for PCR amplification was as follows: $1 \times\left(94^{\circ} \mathrm{C}\right.$ for $\left.2 \mathrm{~min}\right), 5 \times\left(94^{\circ} \mathrm{C}\right.$ for $30 \mathrm{sec}, 45^{\circ} \mathrm{C}$ for $1 \mathrm{sec}, 72^{\circ} \mathrm{C}$ for $3 \mathrm{~min}), 35 \times\left(94^{\circ} \mathrm{C}\right.$ for $30 \mathrm{sec}, 55^{\circ} \mathrm{C}$ for $1 \mathrm{~min}, 72^{\circ} \mathrm{C}$ for $\left.3 \mathrm{~min}\right)$. Reaction products were analyzed on a $1.2 \%$ agarose gel.

\section{Pulse-field gel electrophoresis}

DN A was prepared using an imbedded cell lysis protocol (Carle and Olson 1985). Thirty milliliters of cells was grown in YCLys media to late log phase (O.D. 10.0). Cells were pelleted and washed twice in $50 \mathrm{~mm}$ EDTA at $\mathrm{pH}$ 7.5. The final pellet was resuspended in $1 \mathrm{ml} 50 \mathrm{~mm}$ EDTA at $\mathrm{pH} 7.5$ and placed at $4^{\circ} \mathrm{C}$. Subsequently, $0.75 \mathrm{ml}$ of the resuspended cells were mixed with $0.25 \mathrm{ml}$ of solution 1 ( $1 \mathrm{~m}$ sorbitol, $0.1 \mathrm{M} \mathrm{Na}$ citrate, $60 \mathrm{~mm}$ EDTA at pH 7.0, $1 \mathrm{mg} / \mathrm{myl}$ Zymolase, $5 \% \beta$-mercaptoethanol). During gentle vortexing $1.7 \mathrm{ml}$ of warm $1 \%$ low-melt agarose (125 mm EDTA at $\mathrm{pH}$ 7.5) was added to the mixture and then poured immediately into a 2-ml Petri dish and allowed to solidify at room temperature. Once solidified the plate was covered with $2 \mathrm{ml}$ of solution 2 (0.5 $\mathrm{m}$ EDTA at pH 9.0, $10 \mathrm{~mm}$ Tris at $\mathrm{pH} 8.0,7.5 \% \beta$-mercaptoethanol ) and incubated at $37^{\circ} \mathrm{C}$ overnight in a sealed box. The first overlay was removed and replaced with $1.5 \mathrm{ml}$ of solution $3(10 \mathrm{~mm}$ Tris at $\mathrm{pH} 8.0 ; 0.5 \mathrm{M}$ EDTA at $\mathrm{pH}$ 9.0; $1 \%$ Sarkosyl; $1 \mathrm{mg} / \mathrm{ml}$ proteinase $\mathrm{K}$ ) and incubated at $50^{\circ} \mathrm{C}$ overnight. Solution 3 was removed and the 
plates overlayed with $0.5 \mathrm{M}$ EDTA at pH 9.0 and stored at $4^{\circ} \mathrm{C}$. Plugs were cut out of the agarose using a glass cover slip and placed in the wells of a $1.5 \%$ agarose gel in $0.5 \times$ TBE. Chromosome separation was done using a Bio-Rad CHEF-DR II pulsed field gel electro phoresis (PFGE) system run for $24 \mathrm{hr}$ at $200 \mathrm{~V}$ with a 90-sec switch time. After electrophoresis, the gel was treated for $30 \mathrm{~min}$ in $\sim 40 \mu \mathrm{g} / \mathrm{ml} \mathrm{RN}$ ase and stained subsequently with $\mathrm{EtBr}$ and photographed. The gel was treated with $0.25 \mathrm{M} \mathrm{HCl}$ for $15 \mathrm{sec}$ prior to Southern blotting (see above).

\section{Acknowledgments}

We thank Catherine Freudenreich, Andressa Ivessa, and ShuChun Teng for critical reading of the manuscript. We thank Taryn Phippen for help with some of the experiments. In addition, we thank past and present members of the Zakian Iaboratory for many helpful discussions and suggestions during the course of this work. This work was supported by National Institutes of Health $(\mathrm{NIH})$ grants GM 26938 and GM 43265 to V.A.Z. and an NIH postdoctoral fellowship to J.B.S. (GM 13307).

The publication costs of this article were defrayed in part by payment of page charges. This article must therefore be hereby marked 'advertisement' in accordance with 18 USC section 1734 solely to indicate this fact.

\section{References}

Aguilera, A. and H.L. Klein. 1989. Genetic and molecular analysis of recombination events in Saccharomyces cerevisiae occurring in the presence of the hyper-recombination mutation hpr1. Genetics 122: 503-517.

Aparicio, O.M., B.L. Billington, and D.E. Gottschling. 1991. Modifiers of position effect are shared between telomeric and silent mating-type loci in S. cerevisiae. Cell 66: 12791287.

Ashley, T. 1994. Mammalian meiotic recombination: A reexamination. Hum. Genet. 94: 587-593.

Ashley, T. and D.C. Ward. 1993. A 'hot spot' of recombinaton coincides with an interstitial telomeric sequence in the Armenian hamster. Cytogenet. Cell Genet. 62: 169-171.

Baudat, F. and A. Nicolas. 1997. Clustering of meiotic doublestrand breaks on yeast chromosome III. Proc. Natl. Acad. Sci. 94: 5213-5218.

Berman, J., C.Y. Tachibana, and B.-K. Tye. 1986. Identification of a telomere-binding activity from yeast. Proc. Natl. Acad. Sci. 83: 3713-3717.

Biessmann, H., J. Donath, and M.F. Walter. 1996. Molecular characterization of the A nopheles gambiae $2 \mathrm{~L}$ tel omeric re gion via an integrated transgene. Insect Mol. Biol. 5: 11-20.

Boeke, J.D., J. Trueheart, G. N atsoulis, and G.R. Fink. 1987. 5-Flouroorotic acid as a selective agent in yeast molecular genetics. Methods Enzymol. 154: 164-175.

Boulton, S.J. and S.P. Jackson. 1996. Identification of a Saccharomyces cerevisiae Ku80 homologue: Roles in DN A double strand break rejoining and in telomeric maintenance. Nucleic Acids Res. 24: 4639-4648.

Bourns, B.D., M.K. Alexander, A.M. Smith, and V.A. Zakian. 1998. Sir proteins, Rif proteins, and Cdc13p bind Saccharomyces telomeres in vivo. Mol. Cell. Biol. 18: 5600-5608.

Braunstein, M., A.B. Rose, S.G. Holmes, C.D. Allis, and J.R. Broach. 1993. Transcriptional silencing in yeast is associated with reduced nucl eosome acetylation. Genes \& Dev. 7: 592604.

Brown, W.R.A., P.J. Mackinnon, A. Villasante, N. Spurr, V.J.
Buckle, and M.J. Dobson. 1990. Structure and polymorphism of human telomere-associated DNA. Cell 63: 119-132.

Carle, G.F. and M.V. Olson. 1985. An el ectrophoretic karyotype for yeast. Proc. Natl. Acad. Sci. 82: 3756-3760.

Cheung, W.Y., T.A. Money, S. Abbo, K.M. Devos, M.D. Gale, and G. M oore. 1994. A family of rel ated sequences associated with (TTTAGGG) $n$ repeats are located in the interstitial regions of wheat chromosomes. Mol. \& Gen. Genet. 245: 349354.

Conrad, M.N., J.H. Wright, A.J. Wolf, and V.A. Zakian. 1990. RAP1 protein interacts with yeast telomeres in vivo: Overproduction al ters tel omere structure and decreases chromosome stability. Cell 63: 739-750.

Dani, G.M . and V.A. Zakian. 1983. Mitotic and mei otic stability of linear plasmids in yeast. Proc. Natl. Acad. Sci. 80: 34063410.

de Lange, T. 1995. Telomere dynamics and genome instability in human cancer. In Telomeres (ed. E.H. Blackburn and C.W. Greider), pp. 265-293. Cold Spring Harbor Laboratory Press, Cold Spring Harbor, NY.

Dubey, D.D., L.R. Davis, S.A. Greenfeder, L.Y. Ong, J.G. Zhu, J.R. Broach, C.S. Newlon, and J.A. Huberman. 1991. Evidence suggesting that the ARS el ements associated with silencers of the yeast mating-type locus $\mathrm{HML}$ do not function as chromosomal DNA replication origins. Mol. Cell. Biol. 11: 5346-5355.

Feldmann, H. and E.L. Winnacker. 1993. A putative homologue of the human autoantigen $\mathrm{Ku}$ from Saccharomyces cerevisiae. J. Biol. Chem. 268: 12895-12900.

Ferguson, B.M. and W.L. Fangman. 1992. A position effect on the time of replication origin activation in yeast. Cell 68 : 333-339.

Ferguson, B.M., B.J. Brewer, A.E. Reynolds, and W.L. Fangman. 1991. A yeast origin of replication is activated late in $S$ phase. Cell 65: 507-515.

Firmenich, A.A., E.-A. Elias-M ontserrat, and P. Berg. 1995. A novel allele of Saccharomyces cerevisiae RFA 1 that is deficient in recombination and repair and suppressible by RAD52. Mol. Cell. Biol. 15: 1620-1631.

Fishman-Lobell, J., N. Rudin, and J.E. Haber. 1992. Two alternative pathways of double-strand break repair that are kinetically separable and independently modulated. Mol. Cell. Biol. 12: 1292-1303.

Garvik, B., M. Carson, and L. Hartwell. 1995. Single-stranded DN A arising at telomeres in cdc13 mutants may constitute a specific signal for the RAD9 checkpoint. Mol. Cell. Biol. 15: 6128-6138.

Gilson, E., M. Roberge, R. Giral do, D. Rhodes, and S.M. Gasser. 1993. Distortion of the DNA double helix by RAP1 at silencers and multiple telomeric binding sites. J. Mol. Biol. 231: 293-310.

Gotta, M., T. Laroche, A. Formenton, L. M aillet, H. Scherthan, and S.M. Gasser. 1996.. The clustering of tel omeres and colocalization with Rap1, Sir3, and Sir4 proteins in wild-type Saccharomyces cerevisiae. J. Cell Biol. 134: 1349-1363.

Gotta, M., S. Strahl-Bolsinger, H. Renauld, T. Laroche, B.K. Kennedy, M. Grunstein, and S.M. Gasser. 1997. Localization of Sir2p: The nucleolus as a compartment for silent information regulators. EMBO J. 16: 3243-3255.

Gottlieb, S. and R.E. Esposito. 1989. A nw role for a yeast transcriptional silencer gene, SIR2, in regulation of recombination in ribosomal DNA. Cell 56: 771-776.

Gottschling, D.E., O.M. A paricio, B.L. Billington, and V.A. Zakian. 1990. Position effect at S. cerevisiae tel omeres: Reversible repression of Pol II transcription. Cell 63: 751-762.

Grandin, N., S.I. Reed, and M. Charbonneau. 1997. Stn1, a new 
Saccharomyces cerevisiae protein, is implicated in tel omere size regulation in association with Cdc13. Genes \& Dev. 11: 512-527.

Gravel, S., M. Larrivee, P. Labrecque, and R. Wellinger. 1998. Y east $\mathrm{Ku}$ as a regulator of chromosomal DNA end-structure. Science (in press).

Greider, C.W. 1995. Telomerase biochemistry and regulation. In Telomeres (ed. E.H. Blackburn and C.W. Greider), pp. 3568. Cold Spring Harbor Laboratory Press, Cold Spring Harbor, NY.

Hardy, C.F., L. Sussel, and D. Shore. 1992. A RAP1-interacting protein involved in transcriptional silencing and telomere length regulation. Genes \& Dev. 6: 801-814.

Henderson, E. 1995. Telomere DN A structure. In Telomeres (ed. E.H. Blackburn and C.W. Greider), pp. 11-34. Cold Spring Harbor Laboratory Press, Cold Spring Harbor, NY.

Horn, D. and G.A. Cross. 1995. A developmentally regulated position effect at a telomeric locus in Trypanosoma brucei. Cell 83: 555-561.

Kadyk, L.C. and L.H. Hartwell. 1993. Replication-dependent sister chromatid recombination in radl mutants of Saccharomyces cerevisiae. Genetics 133: 469-487.

Kimmerly, W.J. and J. Rine. 1987. Replication and segregation of plasmids containing cis-acting regulatory sites of silent mating-type genes in Saccharomyces cerevisiae are controlled by the SIR genes. Mol. Cell. Biol. 7: 4225-4237.

Kipling, D., H.E. Wilson, E.J. Thomson, M. Lee, J. Perry, S. Palmer, A. A shworth, and H.J. Cooke. 1996. Structural variation of the pseidoautosomal region between and within inbred mouse strains. Proc. Natl. Acad. Sci. 93: 171-175.

Klein, H.L. 1995. Genetic control of intrachromosomal recombination. BioEssays 17: 147-159.

Klein, F., T. Laroche, M.E. Cardenas, J.F. Hofmann, D. Schweizer, and S.M. Gasser. 1992. Localization of RAP1 and topoisomerase II in nucleic and meiotic chromosomes of yeast. J. Cell. Biol. 117: 935-948.

Klein, S., D. Zenvirth, V. Dror, A.B. Barton, D.B. Kaback, and G. Simchen. 1996. Patterns of meiotic double-strand breakage on native and artificial yeast chromosomes. Chromosoma 105: 276-284.

Kyrion, G., K.A. Boakye, and A.J. Lustig. 1992. C-terminal truncation of RAP1 results in the deregulation of telomere size, stability, and function in Saccharomyces cerevisiae. Mol. Cell. Biol. 12: 5159-5173.

Kyrion, G., K. Liu, C. Liu, and A.J. Lustig. 1993. RAP1 and tel omere structure regulate tel omere position effects in Saccharomyces cerevisiae. Genes \& Dev. 7: 1146-1159.

Laroche, T., S.G. Martin, H.C. Gorham, F.E. Pryde, E.J. Louis, and S.M. Gasser. 1998 Mutation of Ku protein homologues disrupts the subnuclear organization of yeast telomeres. Curr. Biol. 8: 653-656.

Lea, D.E. and C.A. Coulson. 1949. The distribution of the numbers of mutants in bacterial populations. J. Genet. 49: 264285.

Lendvay, T.S., D.K. Morris, J. Sah, B. Balasubramanian, and V. Lundblad. 1996. Senescence mutants of Saccharomyces cerevisiae with a defect in telomere replication identify three additional EST genes. Genetics 144: 1399-1412.

Levis, R., T. Hazelrigg, and G.M. Rubin. 1985. Effects of genomic position on the expression of transduced copies of the white gene of Drosophila. Science 229: 558-561.

Li, B. and A.J. Lustig. 1996. A novel mechanism for telomere size control in Saccharomyces cerevisiae. Genes \& Dev. 10: $1310-1326$.

Lin, F.-L., K. Perle, and N. Sternberg. 1984. Model for homologous recombination during transfer of DNA into mouse $L$ cells: Rolefor DNA ends in the recombination process. Mol. Cell. Biol. 4: 1020-1034.

Lin, J.J. and V.A. Zakian. 1996. The Saccharomyces CDC13 protein is a single-strand $\mathrm{TG}_{1-3}$ tel omeric DN A binding protein in vitro that affects telomere behavior in vivo. Proc. Nat. Acad. Sci. 93: 13760-13765.

Lopez, C.C., L. Nielsen, and J.E. Edstrom. 1996. Terminal Iong tandem repeats in chromosomes from Chironomous pallidivittatus. Mol. Cell. Biol. 16: 3285-3290.

Louis, E.J., E.S. Naumova, A. Lee, G. Naumov, and J.E. Haber. 1994. The chromosome end in yeast: Its mosaic nature and influence on recombinational dynamics. Genetics 136: 789802.

Lundblad, V. and E.H. Blackburn. 1993. An al ternative pathway for yeast tel omere maintenance rescues est-senescence. Cell 73: 347-360.

Lundblad, V. and J.W. Szostak. 1989. A mutant with a defect in telomere elongation leads to senescence in yeast. Cell 57: 633-643.

Luria, S.E. and M. Delbruck. 1943. Mutations of bacteria from virus sensitivity to virus resistance. Genetics 28: 491-511.

Marcand, S., E. Gilson, and D. Shore. 1997. A protein-counting mechanism for telomere length regulation in yeast. Science 275: 986-990.

McEachern, M.J. and E.H. Blackburn. 1995. Runaway telomere el ongation caused by telomerase RN A gene mutations. Nature 376: 403-409.

Meyne, J., R.J. Baker, H.H. Hobart, T.C. Hsu, O.A. Ryder, O.G. Ward, J.E. Wiley, D.H. Wurster-Hills, T.L. Yates, and R.K. Moyzis. 1990. Distribution of non-telomeric sites of the (TTAGGG) $)_{\mathrm{n}}$ telomeric sequence in vertebrate chromosomes. Chromosoma 99: 3-10.

Miklos, G.L.G. and R.N. N ankivell. 1976. Telomeric satellite DN A functions in regulating recombination. Chromosoma 56: 143-167.

Moazed, D., A. Kistler, A. Axelrod, J. Rine, and A. Johnson. 1997. Silent information regulator protein complexes in Saccharomyces cerevisiae: A SIR2/SIR4 complex and evidence for a regulatory domain in SIR4 that inhibits its interaction with SIR3. Proc. Natl. Acad. Sci. 94: 2186-2191.

Moretti, P., K. Freeman, L. Coodly, and D. Shore. 1994. Evidence that a complex of SIR proteins interacts with the silencer and telomere-binding protein RAP1. Genes \& Dev. 8: 2257-2269.

M urnane, J.P., L. Sabatier, B.A. M arder, and W.F. M organ. 1994. Telomere dynamics in an immortal human cell line. EMBO J. 13: 4953-4962.

Nimmo, E.R., G. Cranston, and R.C. Allshire. 1994. Telomereassociated chromosome breakage in fission yeast results in variegated expression of adjacent genes. EMBO J. 13: 38013811.

Nugent, C.I., T.R. Hughes, N.F. Lue, and V. Lundblad. 1996. Cdc13p: A single-strand telomeric DNA-binding protein with a dual role in yeast telomere maintenance. Science 274: 249-252.

Ozenberger, B.A. and G.S. Roeder. 1991. A unique pathway of double-strand break repair operates in tandemly repeated genes. Mol. Cell. Biol. 11: 1222-1231.

Palladino, F., T. Laroche, E. Gilson, A. Axelrod, L. Pillus, and S.M. Gasser. 1993. SIR3 and SIR4 proteins are required for the positioning and integrity of yeast telomeres. Cell 75: 543-555.

Park, V.M., K.M. Gustashaw, and T.M. Wathen. 1992. The presence of interstitial tel omeric sequences in the constitutional chromosome abnormalities. Am. J. Human Genet. 50: 914923. 
Petes, T.D., R.E. Malone, and L.S. Symington. 1991. Recombination in yeast. In The molecular and cellular biology of the yeast Saccharomyces: Genome dynamics, protein synthesis and energetics (ed. J.R. Broach, J.R. Pringle and E.W. Jones), pp. 407-521. Cold Spring Harbor Laboratory Press, Cold Spring Harbor, NY.

Pluta, A.F. and V.A. Zakian. 1989. Recombination occurs during tel omere formation in yeast. Nature 337: 429-433.

Polotnianka, R.M., J. Li, and A.J. Lustig. 1998. The yeast ku heterodimer is essential for protection of the telomere against nucleolytic and recombinational activities. Curr. Biol. 8: 831-834.

Prado, F. and A. Aguilera. 1995. Role of reciprocal exchange, one-ended invasion crossover and single-strand annealing on inverted and direct repeat recombination in yeast: Different requirements for the RAD 1, RAD 10, and RAD 52 genes. Genetics 139: 109-123.

Rajnarayan, S., J.C. Vaughn, and J.K. Bhattacharjee. 1992. Physical and biochemical characterization of the cloned LYS5 gene required for al pha-aminoadipate reductase activity in the Iysine biosynthetic pathway of Saccharomyces cerevisiae. Curr. Genet. 21: 13-16.

Renauld, H., O.M. A paricio, P.D. Zierath, B.L. Billington, S.J. Chhablani, and D.E. Gottschling. 1993. Silent domains are assembled continuously from the telomere and are defined by promoter distance and strength, and SIR3 dosage. Genes \& Dev. 7: 1133-1145.

Reynolds, A.E., R.M. McCarroll, C.S. Newlon, and W.L. Fangman. 1989. Time of replication of ARS el ements al ong yeast chromosome III. Mol. Cell. Biol. 9: 4488-4494.

Rine, J. and I. Herskowitz. 1987. Four genes responsible for a position effect on expression from HML and HMR in Saccharomyces cerevisiae. Genetics 116: 9-22.

Rogan, E.M., T.M. Bryan, B. Hukku, K. Maclean, A.C.-M Chang, E.L. Moy, A. Englezou, S.G. Warneford, L. DallaPozza, and R.R. Reddel. 1995. Alterations in p53 and p16 $6^{\text {IN K4 }}$ expression and telomere length during spontaneous immortalization of li-fraumeni syndrome fibroblasts. Mol. Cell. Biol. 15: 4745-4753.

Rudenko, G., P.A. Blundell, A. Dirks-Mulder, R. Kieft, and P. Borst. 1995. A ribosomal DNA promoter replacing the promoter of a telomeric VSG gene expression site can be efficiently switched on and off in T. brucei. Cell 83: 547-553.

Sandell, L.L. and V.A. Zakian. 1993. Loss of a yeast telomere: Arrest, recovery and chromosome loss. Cell 75: 729-739.

Santos-Rosa, H. and A. Aguilera. 1994. Increase in incidence of chromosome instability and non-conservative recombination between repeats in Saccharomyces cerevisiae hprl strains. Mol. Gen. Genet. 245: 224-236.

Shore, D. and K. N asmyth. 1987. Purification and cloning of a DNA binding protein from yeast that binds to both silencer and activator elements. Cell 51: 721-732.

Sikorski, R.S. and P. Hieter. 1989. A system of shuttle vectors and yeast host strains designed for efficient manipulation of DNA in Saccharomyces cerevisiae. Genetics 122: 19-27.

Singer, M.S. and D.E. Gottschling. 1994. TLC1, the template RN A component of the Saccharomyces cerevisiae telomerase. Science 266: 404-409.

Stavenhagen, J.B. and V.A. Zakian. 1994. Internal tracts of telomeric DNA act as silencers in Saccharomyces cerevisiae. Genes \& Dev. 8: 1411-1422.

Stringer, J.R. 1985. Recombintion between poly[d(GT)-d(CA)] sequences in simian virus 40 -infected cultured cells. Mol. Cell. Biol. 5: 1247-1259.

Sugawara, N., E.L. Ivanov, J. Fishman-Lobell, B.L. Ray, X. Wu, and J.E. Haber. 1995. DNA structure-dependent require- ments for yeast RAD genes in gene conversion. Nature 373: 84-86.

Szostak, J.W. 1983. Replication and resolution of telomeres in yeast. Cold Spring Harbor Symp. Quant. Biol. 47: 11871194.

Tracey, R.B., J.K. Baumohl, and S.C. Kowalczykowski. 1997. The preference for GT-rich DNA by the yeast RAD51 protein defines a set of universal pairing sequences. Genes \& Dev. 11: 3423-3431.

Tracey, R.B., F. Chedin, and S.C. Kowalczykowski. 1996. The recombination hot spot chi is embedded within islands of preferred DNA pairing sequences by the Escherichia coli RecA protein. Cell 90: 205-216.

Treco, D. and N. Arnheim. 1986. The evolutionary conserved repetitive sequence $\mathrm{d}(\mathrm{GT}-\mathrm{AC})_{\mathrm{n}}$ promotes reciprocal exchange and generates unusual recombination tetrads during yeast meiosis. Mol. Cell. Biol. 6: 3934-3947.

Tsukamoto, Y., J.-I. Kato, and H. Ikeda. 1997. Silencing factors participate in DNA repair and recombination in Saccharomyces cerevisiae. Nature 388: 900-903.

Verhage, R., A.-M . Zeeman, N. de Groot, F. Gleig, D.D. Bang, P. van de Putte, and J. Brouwer. 1994. The RAD7 and RAD16 genes are essential for pyrimidine dimer removal from silent mating type loci, are also required for the repair of the nontranscribed strand of an active gene in Saccharomyces cerevisiae. Mol. Cell. Biol. 14: 6135-6142.

Walmsley, R.M., C.S.M. Chan, B.-K. Tye, and T.D. Petes. 1984. Unusual DNA sequences associated with the ends of yeast chromosomes. Nature 310: 157-160.

Wang, S.-S. and V.A. Zakian. 1990. Telomere-telomere recombination provides an express pathway for telomere acquisition. Nature 345: 456-458.

Wellinger, R.J., A.J. Wolf, and V.A. Zakian. 1993. Origin activation and formation of single-strand $\mathrm{TG}_{1-3}$ tails occur sequentially in late $S$ phase on a yeast linear plasmid. Mol. Cell. Biol. 13: 4057-4065.

White, C.I. and J.E. Haber. 1990. Intermediates of recombination during mating type switching in Saccharomyces cerevisiae. EMBO J. 9: 633-670.

White, M.A., M. Wierdl, P. Detloff, and T.D. Petes. 1991. DNAbinding protein RAP1 stimulates mei otic recombination at the HIS4 locus in yeast. Proc. Natl. Acad. Sci. 88: 9755-9759.

Wotton, D. and D. Shore. 1997. A novel Raplp-interacting factor, Rif2p, cooperates with Rif1p to regulate tel omere length in Saccharomyces cerevisiae. Genes \& Dev. 11: 748-760.

Wright, J.H., D.E. Gottschling, and V.A. Zakian. 1992. Saccharomyces telomeres assume a non-nucleosomal chromatin structure. Genes \& Dev. 6: 197-210.

Wright, J.H. and V.A. Zakian. 1995. Protein-DNA interactions in soluble telosomes from Saccharomyces cerevisiae. Nucleic Acids Res. 23: 1454-1460.

Zakian, V.A. 1996. Structure, function and replication of Saccharomyces cerevisiae telomeres. In Annual Review of Ge netics (ed. A. Campbell, W. Anderson, and E.W. Jones), pp. 141-172. Annual Reviews, Palo Alto, CA.

Zamb, T.J. and T.D. Petes. 1981. Unequal sister-strand recombination within yeast ribosomal DNA does not require the RAD52 gene product. Curr. Genet. 3: 125-132.

Zhu, J., C.S. N ewlon, and J.A. Huberman. 1992. Localization of a DN A replication origin and termination zone on chromosome III of Saccharomyces cerevisiae. Mol. Cell. Biol. 12: 4733-4741. 


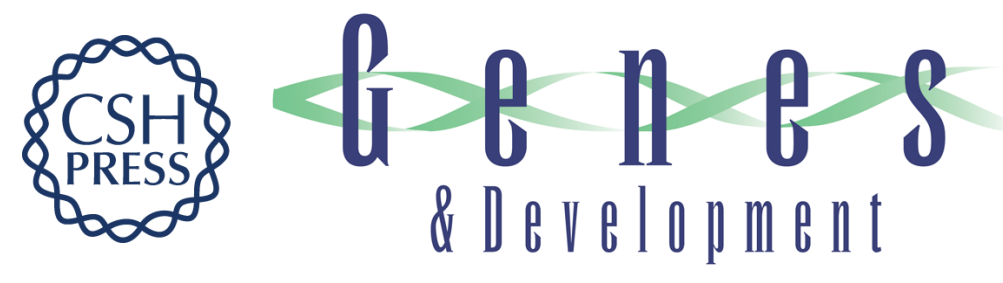

\section{Yeast telomeres exert a position effect on recombination between internal tracts of yeast telomeric DNA}

Jeffrey B. Stavenhagen and Virginia A. Zakian

Genes Dev. 1998, 12:

Access the most recent version at doi:10.1101/gad.12.19.3044

References

This article cites 94 articles, 52 of which can be accessed free at: http://genesdev.cshlp.org/content/12/19/3044.full.html\#ref-list-1

License

Email Alerting

Receive free email alerts when new articles cite this article - sign up in the box at the top Service right corner of the article or click here.

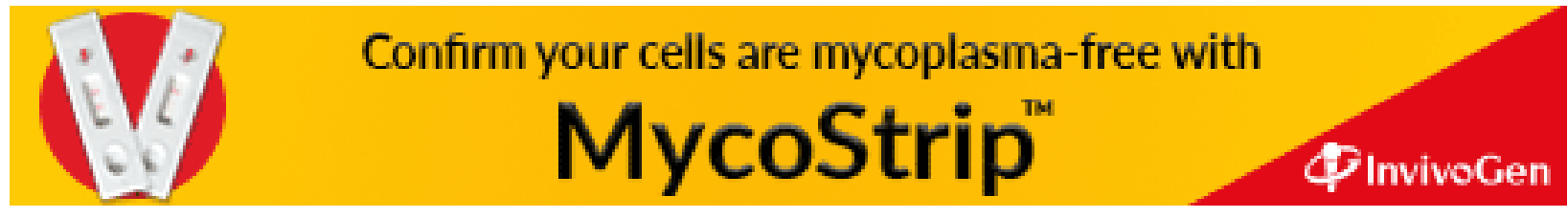

